\title{
INFLUENCE OF CLAY MINERALOGY ON SOIL DISPERSION BEHAVIOR AND WATER QUALITY
}

\author{
A Thesis \\ presented to \\ the Faculty of California Polytechnic State University, \\ San Luis Obispo
}

\author{
In Partial Fulfillment \\ Of the Requirements for the Degree \\ Master of Science in Agriculture, with Specialization in: Soil Science
}

By

Jessique L. Ghezzi

April 2010 
(C) 2010

Jessique L. Ghezzi

ALL RIGHTS RESERVED 


\section{COMMITTEE MEMBERSHIP}

Title:

Author:

Date Submitted:

Committee Chair:

Committee Member:

Committee Member:
Influence of Clay Mineralogy on Soil Dispersion Behavior and Water Quality

Jessique L. Ghezzi

April 2010

Dr. Lynn E. Moody, Earth and Soil Science Department Chair

Dr. William Preston, Geography Department Faculty

Dr. Antonio F. Garcia, Geology Department Faculty 


\begin{abstract}
Influence of Clay Mineralogy on Soil Dispersion Behavior and Water Quality

Jessique L. Ghezzi
\end{abstract}

Currently, there is very little research available on nonpoint source pollution from rural watersheds. Government regulatory agencies are desperate for information regarding the causes of nonpoint source pollution, which includes the relationship between suspended soil particles and dispersion. Since soil dispersion is dependent on clay mineralogy, knowing the clay mineralogy of the soil in an area can help predict sediment loads entering the surrounding surface waters. This information is necessary to protect the resource value of our rivers, lakes, and estuaries, as well as to protect recreational activities such as fishing or hunting; but most importantly, this information is necessary to ensure the safety of our drinking water supply. Clay mineralogy and its influence on dispersion, as well as dispersion and its relation to water quality are the focus of this study. Soil mineralogy affects water quality in several ways: soil mineralogy determines the dispersivity of the clay portion of the soil and dispersive clays are likely to end up as suspended sediment in surface waters; weathering reactions contribute elements to water as dissolved load, and the sorption properties of clay minerals contribute to soils' ability to filter and carry pollutants. Through the use of X-ray diffraction, dispersivity, atomic absorption spectrometry, cation exchange capacity, and petrographic microscopy, this study shows that the clay mineral fraction of a soil determines the dispersivity, and that dispersed clay minerals contribute excess nutrients and metals as nonpoint source pollutants to surface waters. 


\section{ACKNOWLEDGEMENTS}

My research would have been impossible if it were not for my Advisor Dr. Lynn Moody. You are a mentor, a friend and one of the most brilliant people I have ever known. I feel truly blessed to have been able to work with you. I would also like to thank my graduate committee: Dr. Antonio F. Garcia, Dr. William Preston and Dr. Brent Hallock. I cannot begin to thank you for the hours of counsel you have given me on my research. Thank you so very much for all of your help.

I would also like to thank the Earth and Soil Science Department technician Craig Stubler and his assistant Melissa Beck for their help. Thank you to the following undergraduate students who assisted me in my research: Renee Nall, Jacqueline Rudy and Kris Osterloh.

Thank you Dr. Robert Graham and Paul Sternberg at UC Riverside for allowing me to use your XRD. You were fundamental to my research and I appreciate all of your counsel.

Lastly, I would like to give a huge thank you to my family for their support. I could not have done this without you. 


\section{TABLE OF CONTENTS}

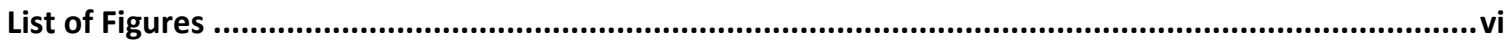

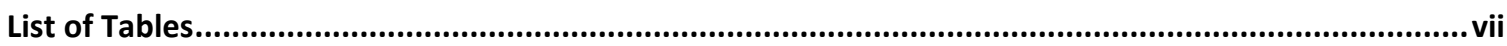

CHAPTER ONE

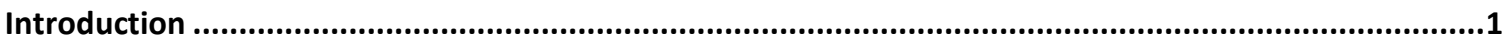

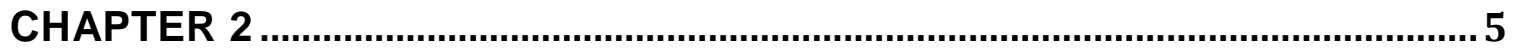

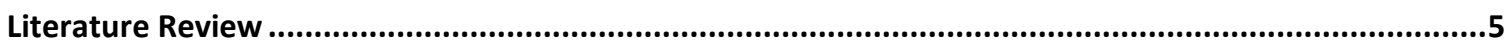

DISPERSION AND CLAY MINERALOGY........................................................... 5

CLAY MINERAL STRUCTURE ............................................................................ 5

INTERACTION BETWEEN CLAY MINERALS AND THE EFFECT ON

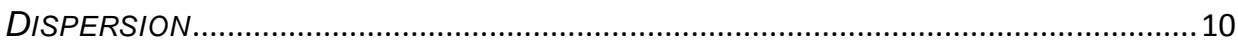

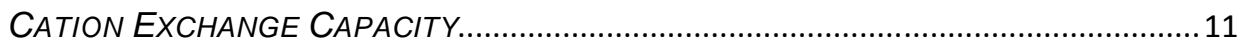

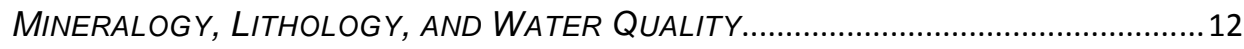

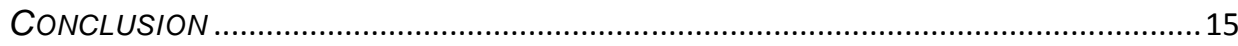

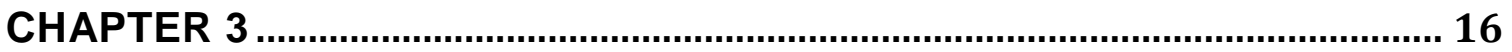

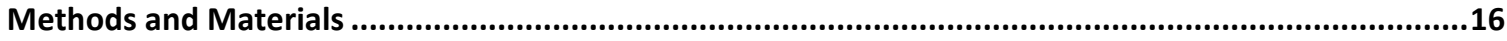

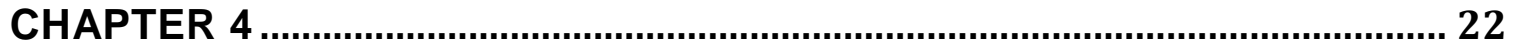

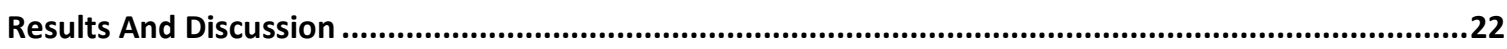

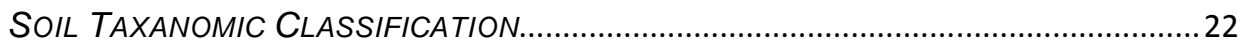

PETROGRAPHIC MICROSCOPE THIN SECTION RESULTS ....................................... 26

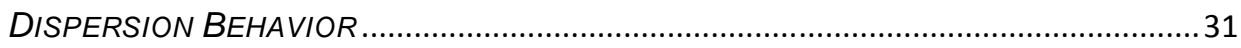

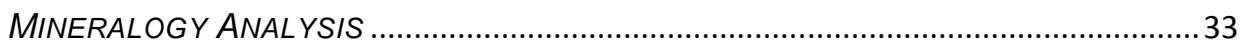

CATION EXCHANGE CAPACITY................................................................. 43

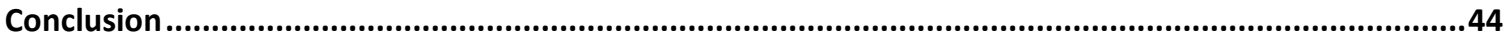

REFERENCES 


\section{LIST OF FIGURES}

Figure 2-1: $(A)$ an exaggerated drawing of the 1:1 phyllosilicate mineral structure showing the tetrahedral sheet and the octahedral sheet, (B) a simplified version of the 1:1 phyllosilicate mineral structure showing the blocky tactoid structure, and (C) a scanning electron microscope picture of a kaolinite aggregate showing the edge-to-face interaction.

Figure 2-2: $(A)$ an exaggerated drawing of the 2:1 phyllosilicate mineral structure showing the tetrahedral sheets and the octahedral sheet, (B) a simplified version of the 2:1 phyllosilicate mineral structure showing the blocky tactoid structure, and (C) a scanning electron microscope picture showing the face-to-face and edge-to-face orientation of individual particles within an aggregate.

Figure 2-3: $(A)$ an exaggerated drawing of the 2:1 phyllosilicate mineral structure showing the tetrahedral sheets and the octahedral sheet, (B) a simplified version of the 2:1 phyllosilicate mineral structure showing the blocky tactoid structure, and (C) a scanning electron microscope picture of illite that has been magnified 3,500 times showing the irregular planar surface.

Figure 2-4: An exaggerated view of the interlayer connection between illite particles .

Figure 2-5: An exaggerated view of smectite binding to the edges of two kaolinite particles, keeping the kaolinite particles from aggregating.

Figure 2-6: Cations adsorption to the surface of a clay particle. 13

Figure 3-1: Thesis site showing the proposed soil pit placements for gathering soil samples from a watershed located in Poly Canyon, on the San Luis Obispo Cal Poly Campus.

Figure 4-1: Thesis site showing the soil pit locations...................................... 24

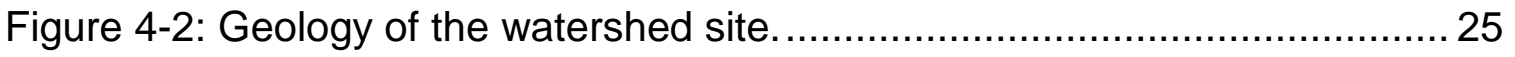

Figure 4-3: Petrographic thin-section portraying the shale parent materials onsite. Pore spaces are lined with goethite iron oxides.

Figure 4-4: Petrographic thin-section (plane polarized light) showing the diabase parent material onsite, which has highly weathered pyroxenes.

Figure 4-5: Petrographic thin-section (cross polarized) showing the diabase parent material onsite, which has highly weathered pyroxenes.

Figure 4-6: Petrographic thin-section (cross polarized) showing the feldspathic greywacke onsite

Figure 4-7: Petrographic thin-section (cross polarized) showing the feldspathic greywacke onsite. 
Figure 4-8: X-ray diffraction pattern for the clay fraction of the A horizon from

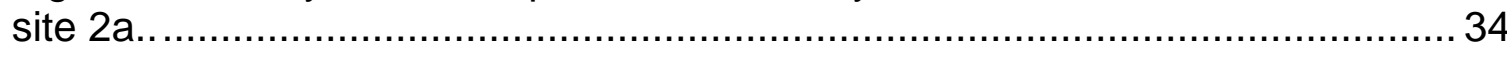

Figure 4-9: X-ray diffraction pattern for the clay fraction of the A horizon from site 3 a.......

Figure 4-10: X-ray diffraction pattern for the clay fraction of the A horizon from site $4 \mathrm{a}$

Figure 4-11: X-ray diffraction pattern for the clay fraction of the A horizon from site 6 ..

Figure 4-12: X-ray diffraction pattern for the clay fraction of the A horizon from the drainage site D1..

Figure 4-13: X-ray diffraction pattern for the clay fraction of the A horizon from the drainage site D2.

\section{LIST OF TABLES}

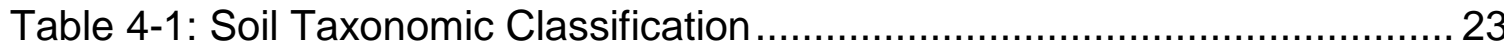

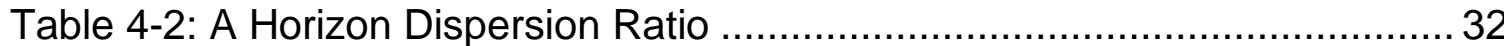

Table 4-3: Mineral Analysis of On-Site Soils ................................................. 42

Table 4-5: Soil Cation Exchange Capacity Values ........................................ 44

Table 4-6: Organic Carbon Content............................................................ 44

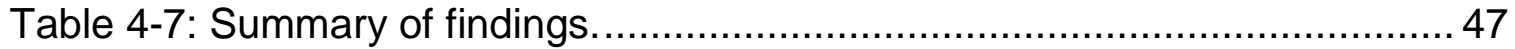




\title{
CHAPTER ONE
}

\author{
INTRODUCTION
}

Soil mineralogy affects water quality in several ways: soil mineralogy determines the dispersivity of the clay portion of the soil and dispersive clays are likely to end up as suspended sediment in surface waters, weathering reactions contribute elements to water as dissolved load, and clay minerals, with their sorption properties, contribute to soils' ability to filter and carry pollutants. Regulatory agencies concerned with the environment, public health and safety, are desperate for what little research has been done on suspended sediments and associated nutrients in regard to water quality (Osidele et al., 2003). Regulatory agencies are also interested in the source of suspended sediments, which is what this study aims to expose. Over the last decade, sedimentation rates of local estuaries have increased by ten times the natural rate (Morro Bay National Estuary Program, 2009). This has resulted in a large increase in contamination of fresh and oceanic waters by metals and nutrients, leading to a movement towards finding the sources of nonpoint source pollution, including suspended sediment in surface waters.

Suspended sediment in surface waters is a concern for water quality because it results in decreased availability of oxygen for aquatic life, an increase in algal blooms, and an increased rate of sedimentation or filling in of local estuaries such as the Morro Bay Estuary on the Central Coast of California. In studies conducted in Chesapeake Bay, Koroncai et al. (2003) and Wang et al., 
(2006) found that a reduction of sediment loads improved water clarity, and thus allowed more processing of nutrients in shallow waters. The degraded water quality in Chesapeake Bay was attributed to algal blooms and reduced water clarity due to excess nutrient and sediment inputs. The same problems have occurred in the Central Coast's Morro Bay Estuary and have been attributed to excess sediment loading from surrounding tributaries (Koroncai et al., 2003; Morro Bay National Estuary Program, 2009; Wang et al., 2006).

Clay particles contribute to suspended sediment in surface waters when soil dispersion occurs. The dispersed soil or sediment susceptible to being eroded retains nutrients and contaminants via adsorption to clay particles (Calero et al., 2008). Currently there is very little research available regarding the direct contribution of dispersed soil to suspended sediment. Therefore, more information is needed regarding the influence of dispersive clays and suspended sediment on water quality.

In this thesis I will address how clay mineralogy relates to soil dispersivity and the likelihood that clays will end up as suspended sediment in surface waters. I will discuss how parent materials determine clay mineralogy, their relation to soil dispersion and water quality. This information will be useful to regulatory agencies for understanding suspended load and for determining whether or not the clay contained in suspended sediments serves as a carrier for pollutants. Understanding the soil-water quality connection could help determine if and what kind of erosion prevention measures would be effective in protecting surface waters and estuaries from continued sediment loading. 


\section{IMPORTANCE OF THE PROJECT}

Clay mineralogy determines soil dispersivity and dispersive clays are likely to end up in water as suspended sediment. Suspended sediment presents water quality issues that negatively affect wildlife, aquatic life, and the safety of public drinking water. Regulatory agencies, concerned with the environment and public health and safety, need more research on suspended sediments and the nutrients and metals carried by suspended sediments in surface water (Osidele et al., 2003).

Suspended sediment consists in part of dispersive clays. Dispersive clays end up in the water supply as suspended load, and are often considered to have a nonpoint source. Suspended particles also carry contaminants and excessive nutrients. Currently there is a paucity of research on nonpoint source pollution from rural watersheds and government agencies are looking to the scientific community to provide more information in this area, including information on soil dispersivity and how dispersion can affect water quality.

Dispersed soils are potentially nonpoint source pollutants and contribute to the sedimentation of estuaries. Eutrophication is a direct result of nonpoint source pollutants such as suspended sediment. Eutrophication is an increase in algal blooms due to high nutrient levels carried in sediments and results in decreased oxygen levels for aquatic life. This results in decreased resource values of rivers, lakes, land estuaries and poses a safety hazard in drinking water treatments (Batram et al., 1999; Koroncai et al., 2003; Morro Bay National Estuary Program, 2009; Wang et al., 2006). 
It is important when examining nonpoint source pollution to consider soil dispersivity as a factor. Since soil dispersivity is dependent on clay mineralogy, knowing the clay mineralogy of an area can help predict sediment loads and erosion rates, and can help determine if sediment loading is a concern for water quality and aquatic life. The goals of my study were to study the behavior of selected soils to determine if there was a relationship between dispersion and clay mineralogy. 


\section{CHAPTER 2}

\section{LITERATURE REVIEW}

\section{Dispersion and CLAY MinERALOGY}

Dispersion of clay particles is when the attractive forces between the particles are not strong enough to hold them together, and they separate from each other. Readily dispersed soil particles indicate the soil's tendency toward unstable aggregates. Soil mineralogy has substantial effects on clay dispersion due to the interactions between clay particles (Lado and Ben-Hur, 2004).

This literature review focused on kaolinite, illite, chlorite, and smectite minerals. Soils containing smectite minerals have been found to be the most dispersive and kaolinitic soils were found to be the least dispersive, while illitic soils were intermediate with few cases exceeding the dispersivity of smectitic soils (Lado and Ben-Hur, 2004; Singer, 1994; Wakindiki and Ben-Hur, 2002).

\section{CLAy MineRal StRucture}

The differing crystal structures of kaolinite, smectite and illite result in different reactions, including dispersion behavior. It is because of the different crystal structures and chemical compositions of smectite, illite, and kaolinite that they have different aggregation behavior, forming clay aggregates that vary in stability and therefore dispersion (Dixon, 1989; Lado and Ben-Hur, 2004; Singer, 1994; van Olphen, 1977). 


\section{Kaolinite}

Kaolinite is a 1:1 phyllosilicate mineral (Fig. 2-1). The term 1:1 refers to the ratio of one tetrahedral sheet to one octahedral sheet in each kaolinite layer (Dixon, 1989). The oxygen ions in the tetrahedral sheet form hydrogen bonds with the hydroxyls in the octahedral sheet to form a blocky tactoid structure (Fig. 2-1). Kaolinite has a low dispersion value because of the edge-to-face interaction between the positively charged edges and negatively charged planar surfaces of the clay sheets (Fig. 2-1) (Frenkel et al., 1992). Due to their uniform structure and strong hydrogen bonds there is better contact between kaolinite sheets than in smectite or illite minerals and therefore kaolinite does not disperse easily.

(A)

(B)

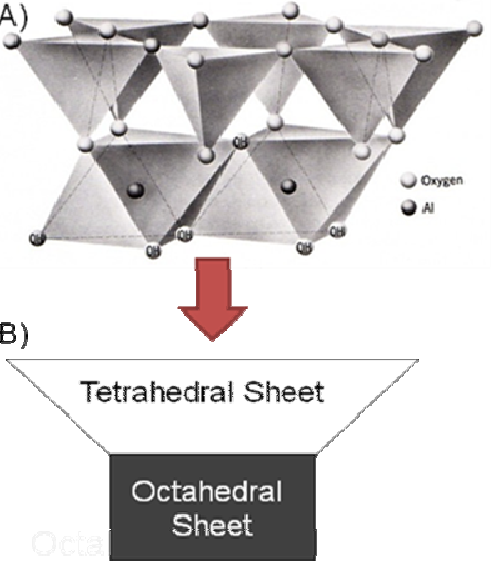

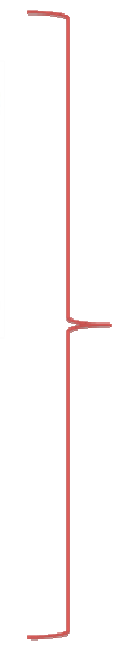

Figure 2-1: (A) an exaggerated drawing of the 1:1 phyllosilicate mineral structure showing the tetrahedral sheet and the octahedral sheet, (B) a simplified version of the 1:1 phyllosilicate mineral structure showing the blocky tactoid structure, and $(\mathrm{C})$ a scanning electron microscope picture of a kaolinite aggregate showing the edge-to-face interaction (Dixon, 1989; Frenkel et al., 1992; Grim, 1968; Klein, 2002; Lado and Ben-Hur, 2004). 


\section{Smectite}

Smectites are a group of minerals with 2:1 phyllosilicate structure (Fig. 22). The term 2:1 refers to the smectite structure of one octahedral sheet sandwiched between two tetrahedral sheets. Smectite particles have face-toface and edge-to-face orientation, being held together by weak Van der Wals forces, polyvalent metal cations, and electrostatic forces that form connections between the negatively charged clay platelets (Fig. 2-2). Smectite has high dispersivity due to water penetration between the clay platelets and the weakness of its edge-to-face contact (Borchardt, 1989; Lado and Ben-Hur, 2004; Singer, 1994; van Olphen, 1977). 
2:1 Phyllosilicate Structure

A)

B)

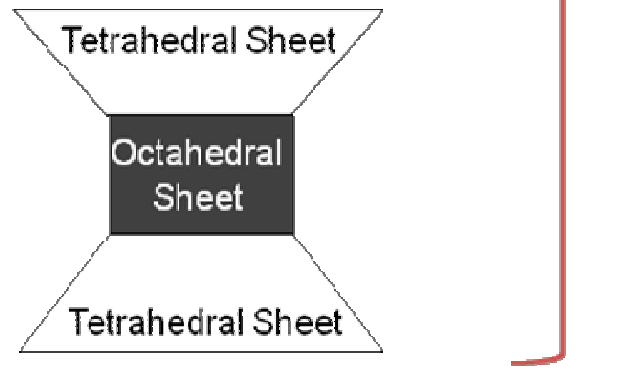

C)

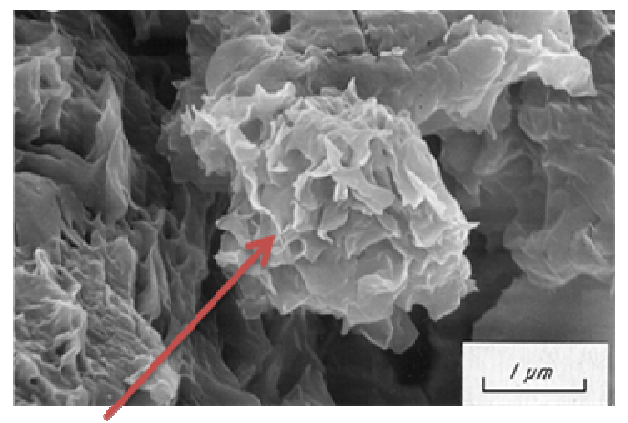

Edge-to-face and face-to-face orientation of smectite particles result in a crumpled appearance of the smectite aggregate.

Figure 2-2: $(A)$ an exaggerated drawing of the 2:1 phyllosilicate mineral structure showing the tetrahedral sheets and the octahedral sheet, (B) a simplified version of the 2:1 phyllosilicate mineral structure showing the blocky tactoid structure, and $(C)$ a scanning electron microscope picture showing the face-to-face and edge-to-face orientation of individual particles within an aggregate (Borchardt, 1989; Frenkel et al., 1992; Grim, 1968; Klein, 2002; Lado and Ben-Hur, 2004).

Illite

Illite is a 2:1 phyllosilicate mineral, as is smectite (Fig. 2-3). There is conflicting research on the morphology of illite, and until more work is completed illite has been classified as a hydrous, non-expanding mica. Minerals in the mica family have interlayer potassium ions between connecting tetrahedral layers (Fig. 2-4). As illite weathers, the interlayer potassium connecting the tactoids is replaced by water molecules. This causes a wedge to form between particles, breaking the bonds between aggregates and increasing illite's dispersivity. Also affecting illite's dispersivity are the irregular, wispy planar surfaces shown in 
electron micrographs (Fig. 2-3). The wispy, irregular surfaces of illite particles cause poor contact between the edge and planar surfaces when the illite tactoids come together, resulting in high dispersivity (Fanning et al., 1989; Lado and BenHur, 2004; Singer, 1994; van Olphen, 1977).

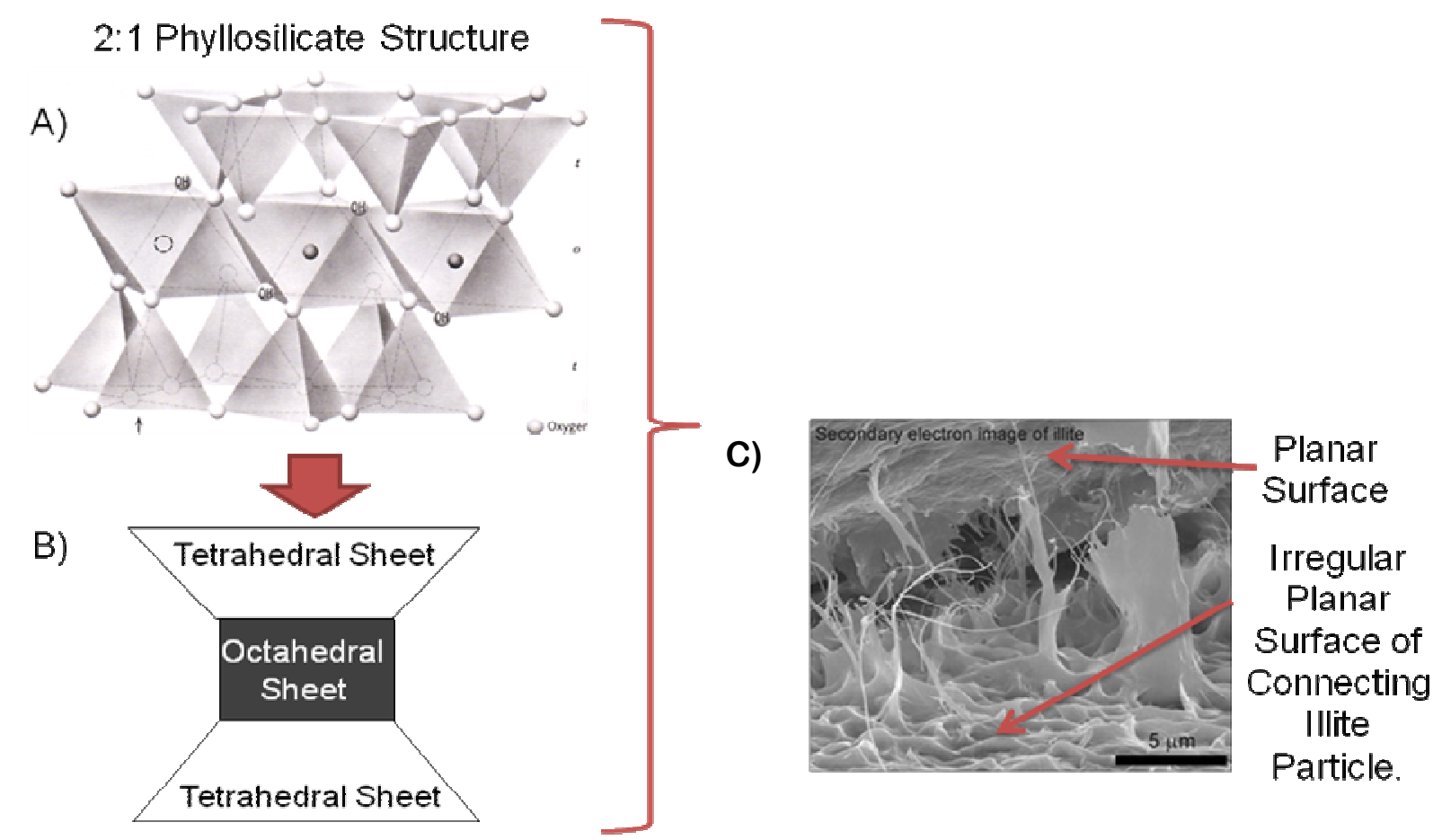

Figure 2-3: $(A)$ an exaggerated drawing of the 2:1 phyllosilicate mineral structure showing the tetrahedral sheets and the octahedral sheet, (B) a simplified version of the 2:1 phyllosilicate mineral structure showing the blocky tactoid structure, and $(C)$ a scanning electron microscope picture of illite that has been magnified 3,500 times showing the irregular planar surface (Barthelmy, 2005; Dixon, 1989; Frenkel et al., 1992; Grim, 1968; Klein, 2002; Lado and Ben-Hur, 2004; University of Glasgow, 2009). 


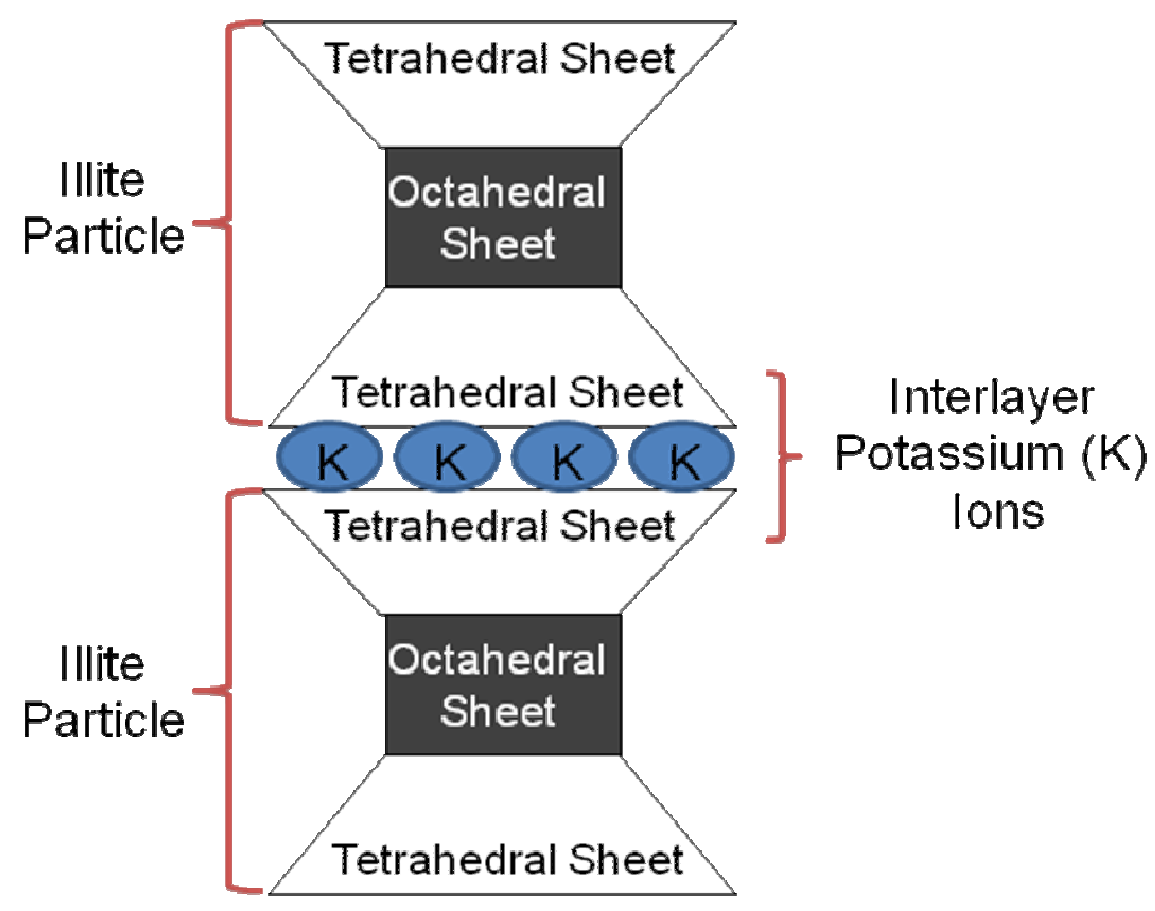

Figure 2-4: An exaggerated view of the interlayer connection between illite particles (adapted from Fanning et al., 1989).

\section{INTERACTION BETWEEN CLAY MINERALS AND THE EFFECT ON DISPERSION}

Kaolinite mixed with small amounts of smectite may become more dispersive than pure kaolinite. In pure kaolinite the attraction between the positive charges on the edges of the kaolinite particles and the negative charges on the planar surfaces causes flocculation, even in the absence of salt. However, when kaolinitic soils have smectite minerals present, the smectite minerals bind to the edges of the mineral so that kaolinite particles cannot have the strong edge-to-face interaction they have when smectite is not present (Fig. 2-5) (Arora and Coleman, 1979). Studies have shown that if the smectite particles are on the positively charged edges of the kaolinite particles, the kaolinite will not flocculate because there is no edge-to-face contact as seen in 
pure kaolinite (Fig. 2-5) (Arora and Coleman, 1979; Lado and Ben-Hur, 2004). In soils containing kaolinite in North Carolina, dispersivity was not affected by $20 \%$ $\mathrm{Na}$ on the exchange complex. However, when these soils were mixed with two percent montmorillonite (a member of the smectite family) it showed higher rates of dispersion than soils containing pure kaolinite (Arora and Coleman, 1979). The presence of smectite (even in small amounts) in kaolinitic soils causes an increase in clay dispersivity (Arora and Coleman, 1979; Lado and Ben-Hur, 2004).

\section{Smectite Interaction with Kaolinite Particles}

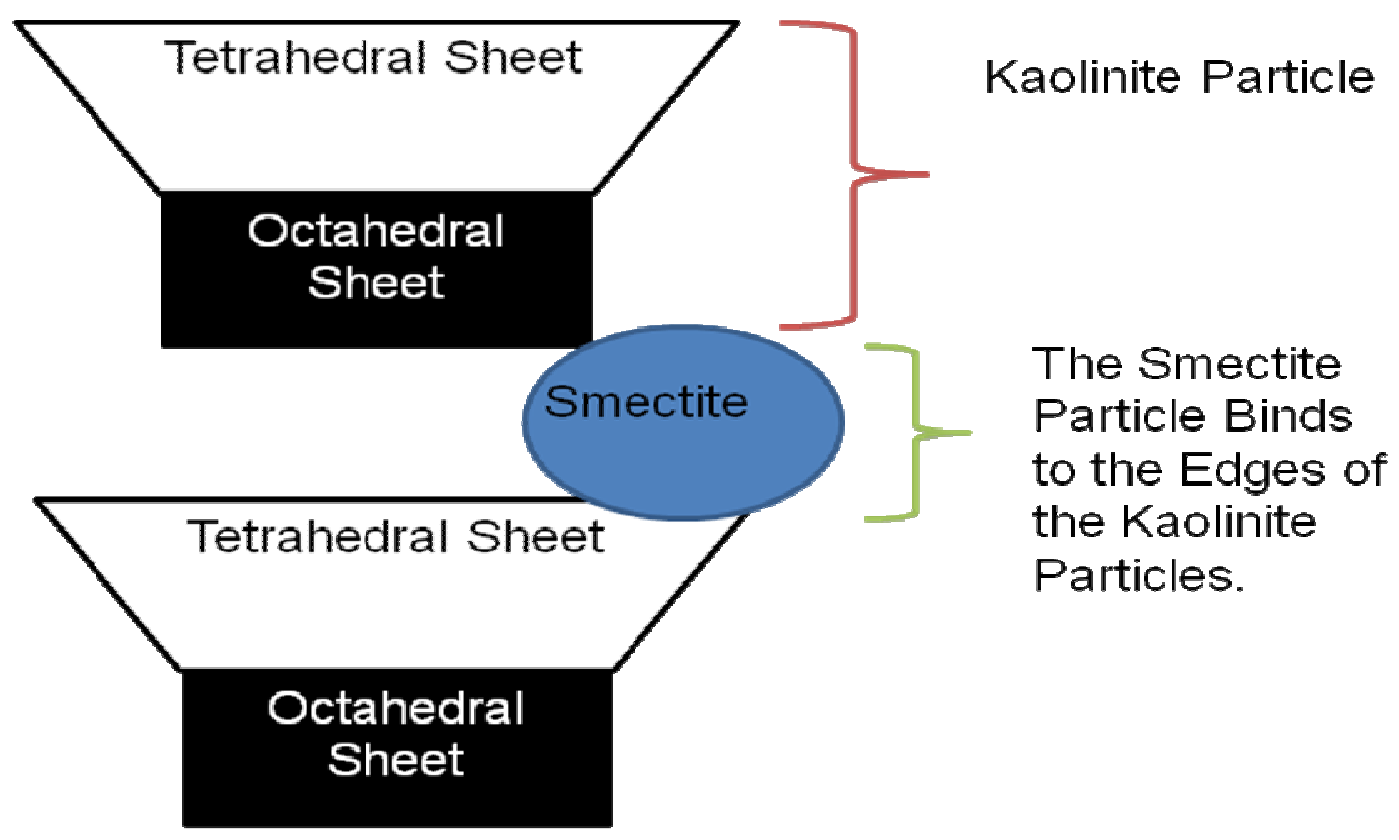

Figure 2-5: An exaggerated view of smectite binding to the edges of two kaolinite particles, keeping the kaolinite particles from aggregating.

\section{CATION EXCHANGE CAPACITY}

The cation exchange capacity (CEC) of a soil is the sum of exchangeable cations that a soil or soil constituent can adsorb at a specific pH. Thus, the CEC 
is a measure of a soil's adsorption capacity (Sparks, 1995). Smectite clays typically have CEC values of 47 to $150 \mathrm{cmolc} / \mathrm{kg}$ (Reid-Soukup and Ulery, 2002). Chlorite minerals typically have CEC values between 1 to $2.5 \mathrm{cmol} / \mathrm{kg}$. It should be noted that the intermediate weathering products of chlorite (sometimes known as hydroxy-interlayered smectites or vermiculites) can increase the CEC and swelling properties of the soil (Kohut and Warren, 2002). Cation exchange capacity values of chlorites with the partial or complete removal of the interlayer hydroxide sheet are as high as $140 \mathrm{cmol} / \mathrm{kg}$. Illite tends to have CEC values between 15 and $40 \mathrm{cmol} / \mathrm{kg}$, however, these values can be influenced by the smectite particles that are often associated with illites (Thompson and Ukrainczyk, 2002). Kaolinite has the lowest charge of the common clay minerals and has CEC values between 1 and $5 \mathrm{cmol} / \mathrm{kg}$ (White and Dixon, 2002). Smectite has the highest expected CEC values, with illite acting as an intermediate, and kaolinite and chlorite having the lowest CEC values.

\section{Mineralogy, LITHOLOGY, aND WATER QUALITY}

Dispersed clay particles contribute to the suspended load in surface waters. Suspended load refers to the particles that remain in suspension in surface waters and is essentially the equivalent of a dust storm on land (U.S. Geological Survey, 2008). The dispersed soil or sediment being eroded carries nutrients and contaminants via adsorption to clay particle surfaces (Fig. 2-6) (Calero et al., 2008). Clay colloids have powerful adsorption properties, which means that the strong negative charge on the surface of a clay particle attracts cations to attach to their surface (Hillel, 1998). The nutrients and contaminants 
likely to be carried via adsorption by clay colloids include ammonia, phosphorus, copper, nickel, selenium, and most metals with the exception of arsenic (Calero et al., 2008; Harper, 1992; Wang et al., 2006; Yoon and Stein, 2008). In this review I will concentrate on the sources of sediment carrying phosphorus and the negative effects they have on water quality.

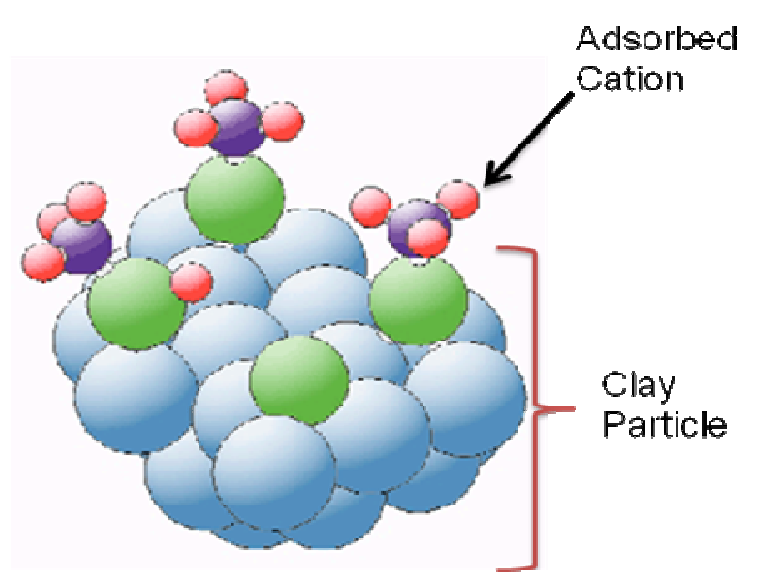

Figure 2-6: Cations adsorption to the surface of a clay particle (adapted from European Synchrotron Radiation Facility, 2007).

The type of soil parent material has an impact on the presence of metals and nutrients in eroded sediments (Yoon and Stein, 2008). Watersheds underlain by sedimentary rock generally have higher concentrations of metals, nutrients, and total suspended solids as compared to watersheds underlain by igneous rock. In southern California, the Monterey Formation (mostly sedimentary rock) has been shown to be a source of phosphate loadings, which may contribute to algal growth in streams due to the decreased availability of oxygen (Bisson et al., 1987; Egli et al, 2008; Horowitz and Elrick, 1987; Richards, 1982; Trefry and Metz, 1985; Yoon and Stein, 2008). 
Calero et al., (2008) studied clay dispersivity in relation to phosphorus concentration, and found that the water dispersible clay portion of the soil carried $1 / 10^{\text {th }}$ of the soil's total phosphorus. They also found that carbonate portions of soils had lower phosphorus adsorption abilities than the silicate clays or iron oxides. Alternative soil carriers for phosphorus include silicate clays and iron oxides. Phosphorus concentrates in the clay portion of the soil due to the high specific surface and reactivity towards phosphorus in the clay minerals (Calero et al., 2008).

Phosphorus adsorption to the clay portion of sediments leads to eutrophication of surface waters. Eutrophication results from nutrient loading of waters by plant nutrients such as phosphorus and nitrogen (Harper, 1992). Increases in sedimentation inputs to watersheds have resulted in an increased rate of eutrophication in surface waters. Eutrophication reduces oxygen availability and may severely degrade water quality, fish and other animal populations (Batram et al., 1999; Koroncai et al., 2003).

In aquatic environments, decomposition of algal blooms resulting from eutrophication cause a lack of oxygen in the water needed for fish to survive. The water becomes cloudy and colored a shade of green, yellow, brown, or red. Human society is impacted by eutrophication as well: eutrophication decreases the resource value of rivers, lakes, and estuaries resulting in decreased recreation, fishing, hunting, and aesthetic enjoyment. Sedimentation and eutrophication is a concern for the Morro Bay Estuary where human impact on the watershed has increased soil erosion and altered natural stream channels. 
Indeed, sedimentation of the bay has been as much as ten times the natural rate. If we can understand the soil's potential erosion rates, we can help prevent or mitigate the problem (Batram et al., 1999; Morro Bay National Estuary Program, 2009).

\section{CONCLUSION}

Sediment loads in surface water have been attributed to decreased water quality and species degradation in watersheds. Sediment loading is a consequence of soils that contain highly dispersive clay minerals and have a higher tendency to erode into surrounding surface waters than do soils without dispersive clay minerals. Therefore, if soil mineralogy is known, predictions can be made regarding the soil's tendency to disperse. Studies have shown that soils high in smectite or clays mixed with smectite minerals are highly dispersive and more likely than kaolinite or illite to end up in surface waters (Lado and BenHur, 2004; Singer, 1994; Wakindiki and Ben-Hur, 2002). This information is crucial for property owners and public agencies wishing to take protective measures to constrain sediment from eroding into surface waters. 


\section{CHAPTER 3}

\section{Methods AND Materials}

The study area is at elevations of 160 to 310 meters, in the Cuesta Ridge portion of the Santa Lucia mountains of San Luis Obispo County, on the Central Coast of California (Fig. 3-1). The climate is Mediterranean with precipitation occurring mostly as rain between the months of November and April. The average temperature is $15^{\circ} \mathrm{C}$ with a mean annual rain fall of 60 centimeters (Country Studies, 2003). The soils in the area are Mollisols, with a Great Group classification of Haploxerolls. The site chosen for investigation is a two-hectare watershed (slopes 29-89\%) located 2.4 kilometers north east of the California Polytechnic State University campus on the Cal Poly Peterson Ranch (West 120 38.723 minutes, North $35^{\circ} 19.222$ minutes) (Fig. 3-1).

The following hypothesis was tested: Clay mineralogy affects dispersion behavior of soils. Ultimately, dispersed clays are likely to end up as suspended sediment in surface waters.

The population sampled was the $\mathrm{A}$ and $\mathrm{Cr} / \mathrm{R}$ horizons of soils considered representative of the landscape and geology, and the A horizon of two soils in the drainageway site. The sample design includes eight hand dug soil pits to a depth of $150 \mathrm{~cm}$ that is to the depth of a $\mathrm{Cr} / \mathrm{R}$ horizon. Due to the slopes present onsite and due to problematic weed infestations that result from disturbances, mechanical means of soil excavation were not allowed on the site. The soil pits were filled after completion of sampling and morphological descriptions and 
reseeded with native grasses. The sampling schematic used to determine soil pit locations was based on changes in vegetation and surface color of the soil, geology, and topographic differences including aspect and landscape position (Fig. 3-1) (Soukup et al., 2008). 


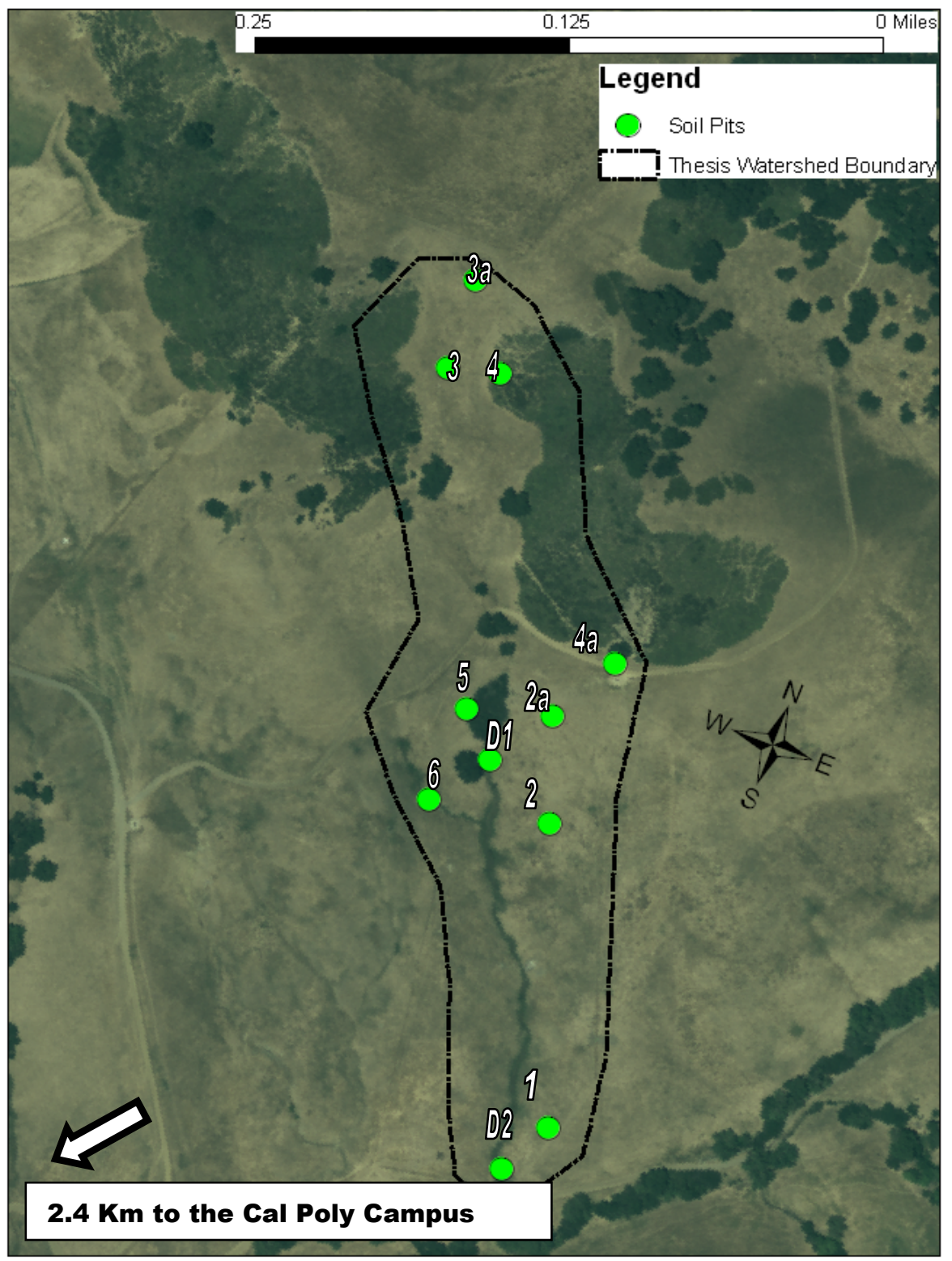

Figure 3-1: Thesis site showing the proposed soil pit placements for gathering soil samples from a watershed located in Poly Canyon, on the San Luis Obispo Cal Poly campus.

Soil samples were collected starting with the bottom horizon and working up to prevent contamination from surface horizon sampling. Soils were air dried and stored in one gallon unsealed plastic bags in storage lockers at room temperature $\left(20^{\circ} \mathrm{C}\right)$. 
Thin sections were made of the $\mathrm{Cr} / \mathrm{R}$ horizons of the soils and viewed under a petrographic microscope to determine the extent of weathering occurring onsite and for later determination of the weathering sequences that form the clay minerals (Lynn et al., 2008). Rock samples of each parent material excavated from the site were taken to a Cal Poly geologist for initial identification. Powder mounts of the parent material were made and analyzed by X-ray diffraction to identify the minerals present (Jackson, 1969).

Particle size analysis by hydrometer and sieve (Gee and Orr, 2002) and dispersion (Volk, 1937) were determined using a double hydrometer study. Particle size analysis followed chemical and mechanical dispersion. Clay mineral identification was made for each representative $\mathrm{A}$ and $\mathrm{Cr} / \mathrm{R}$ horizon using $\mathrm{X}$-ray diffraction (Jackson, 1969). The X-ray diffraction (XRD) samples were also pretreated with the following treatments: removal of carbonates and organic matter, separation of clays, saturation of clays with potassium, sodium, and magnesium, and glycolation of Mg-saturated clays. The sample pretreatments for removal of carbonates and organic matter served to remove non-clay minerals or material that interfere with the clay mineral spectra results such as zeolites, gypsum, calcite, dolomite, and organic matter. Pretreatments for the removal of iron oxides, quartz, feldspars, or pyrite were not performed because too many chemical treatments on a sample results in the changing of the phyllosilicate structures due to their large, reactive surface areas.

The cation saturation pretreatments and glycolation is critical for differentiating vermiculite from smectite (Moore and Reynolds, 1989). In 
magnesium saturated samples vermiculite, smectite and chlorite appear at around the same spacing of $1.4 \mathrm{~nm}$. The magnesium saturated samples are glycolated to separate the smectite minerals. It is important to note that once magnesium saturation and glycolation have been completed the samples need to be immediatly run on XRD. If there are changes in humidity or the slides experience drying then the peaks will shift and give erroneous results. Magnesium saturated samples were stored in a 52\% humidity chamber until XRD was performed. Glycolated samples remained in the glycolation dessicator to maintain sufficient moisture until XRD was performed (Dr. Robert Graham, personal communication, 2009).

Saturation with potassium cations similarly allows the separation of vermiculite from chlorite, which does not collapse. Heating the potassium samples to $550^{\circ}$ Celsius accomplishes two important functions: vermiculite collapses because it contains non-exchangeable interlayer hydroxyl complexes, and the heat destroys kaolin minerals. Eliminating kaolin minerals is important because when chlorite is present it has a second order maximum at nearly the same position as kaolinite or serpentine. If a peak is present at $0.715 \mathrm{~nm}$ maximum in the unheated samples and disappears in the heated samples or decreases in intensity the presence of kaolinite is confirmed (Whittig and Allardice, 1986). Once pretreatments were finished XRD was performed on the samples as described by Jackson (1969), to determine which minerals were present in the clay fraction of the soil. 
The cation exchange capacity (CEC) and the $\mathrm{pH}$ of the soils were measured (Sumner and Miller, 1996; Jackson, 1969). The CEC analysis determined the adsorption abilities of the soils, and the $\mathrm{pH}$ of the soil determined which soils needed the XRD pretreatment for carbonate removal. The organic carbon content of the whole soil was also determined by combustion, using a VarioMax CNS Analyzer.

Error from experimental procedures was minimized by repetition. The particle size analysis and dispersion treatments were run three times and compared with a standard soil. The x-ray diffraction results were compared to similar soil results. The $\mathrm{CEC}$ and $\mathrm{pH}$ of the soils were run three times and compared to standards. 


\section{CHAPTER 4}

\section{RESULts AND Discussion}

\section{SOIL TAXANOMIC CLASSIFICATION}

The studied soils are mostly Haploxerolls, and smectites dominate clay mineralogy (Table 4-1). A horizon textures found onsite are predominantly loams, clay loams and clays with the exception of site 4. 4a, and 3a. Sites 4 and 4a respectively have sandy loam and loamy sand textures and 3a has a silt loam texture. Sites D1 and D2 were not classified because they were sampled from the drainageway, and the soil pits were not dug on this landform. The drainageway is the area dividing the site into two halves. A drainageway is the above ground area where the water onsite gathers and flows to a nearby stream or body of water (Dictionary, 2010). The drainageway samples were taken solely to determine what minerals were being transported into and through the drainageway. The sample site locations are shown in Figure 4-1. 


\begin{tabular}{|c|c|c|c|c|}
\hline $\begin{array}{l}\text { Site } \\
\text { Number }\end{array}$ & $\begin{array}{c}\text { Textural Class of } \\
\text { A Horizon }\end{array}$ & $\begin{array}{l}\text { Clay } \\
\%\end{array}$ & Parent Material & Taxonomic Classification \\
\hline D1 & Loam & 22 & $\begin{array}{l}\text { Mixed colluvium and } \\
\text { alluvium }\end{array}$ & Not determined \\
\hline D2 & Loam & 25 & $\begin{array}{l}\text { Mixed colluvium and } \\
\text { alluvium }\end{array}$ & Not determined \\
\hline 1 & Clay & 45 & $\begin{array}{c}\text { Colluvium over very } \\
\text { weathered graywacke } \\
\text { residuum }\end{array}$ & $\begin{array}{l}\text { Fine, mixed, superactive } \\
\text { thermic Typic Haploxeroll }\end{array}$ \\
\hline 2 & Clay Loam & 30 & $\begin{array}{l}\text { Siliceous shale } \\
\text { residuum }\end{array}$ & $\begin{array}{l}\text { Fine, smectitic, thermic } \\
\text { Typic Haploxeroll }\end{array}$ \\
\hline $2 a$ & Loam & 23 & $\begin{array}{l}\text { Siliceous shale } \\
\text { residuum }\end{array}$ & $\begin{array}{l}\text { Loamy, smectitic, thermic } \\
\text { Lithic Haploxeroll }\end{array}$ \\
\hline 3 & Clay Loam & 35 & Shale colluvium & $\begin{array}{l}\text { Fine, smectitic, thermic } \\
\text { Typic Haploxeroll }\end{array}$ \\
\hline $3 a$ & Silty Clay & 43 & Shale residuum & $\begin{array}{l}\text { Fine, smectitic, thermic } \\
\text { Typic Haploxeroll }\end{array}$ \\
\hline 4 & Loamy Sand & 10 & $\begin{array}{l}\text { Residuum from } \\
\text { Diabase }\end{array}$ & $\begin{array}{l}\text { Coarse-loamy, smectitic } \\
\text { thermic Typic Xerorthent }\end{array}$ \\
\hline $4 a$ & Sandy Loam & 10 & $\begin{array}{l}\text { Residuum from highly } \\
\text { weathered Diabase }\end{array}$ & $\begin{array}{l}\text { Loamy, smectitic, thermic } \\
\text { shallow Typic Xerorthent }\end{array}$ \\
\hline 5 & Clay Loam & 24 & Shale residuum & $\begin{array}{l}\text { Fine, mixed, superactive } \\
\text { thermic Typic Haploxeroll }\end{array}$ \\
\hline 6 & Clay & 45 & Greywacke residuum & $\begin{array}{l}\text { Fine, smectitic, thermic } \\
\text { Typic Haploxeroll }\end{array}$ \\
\hline
\end{tabular}




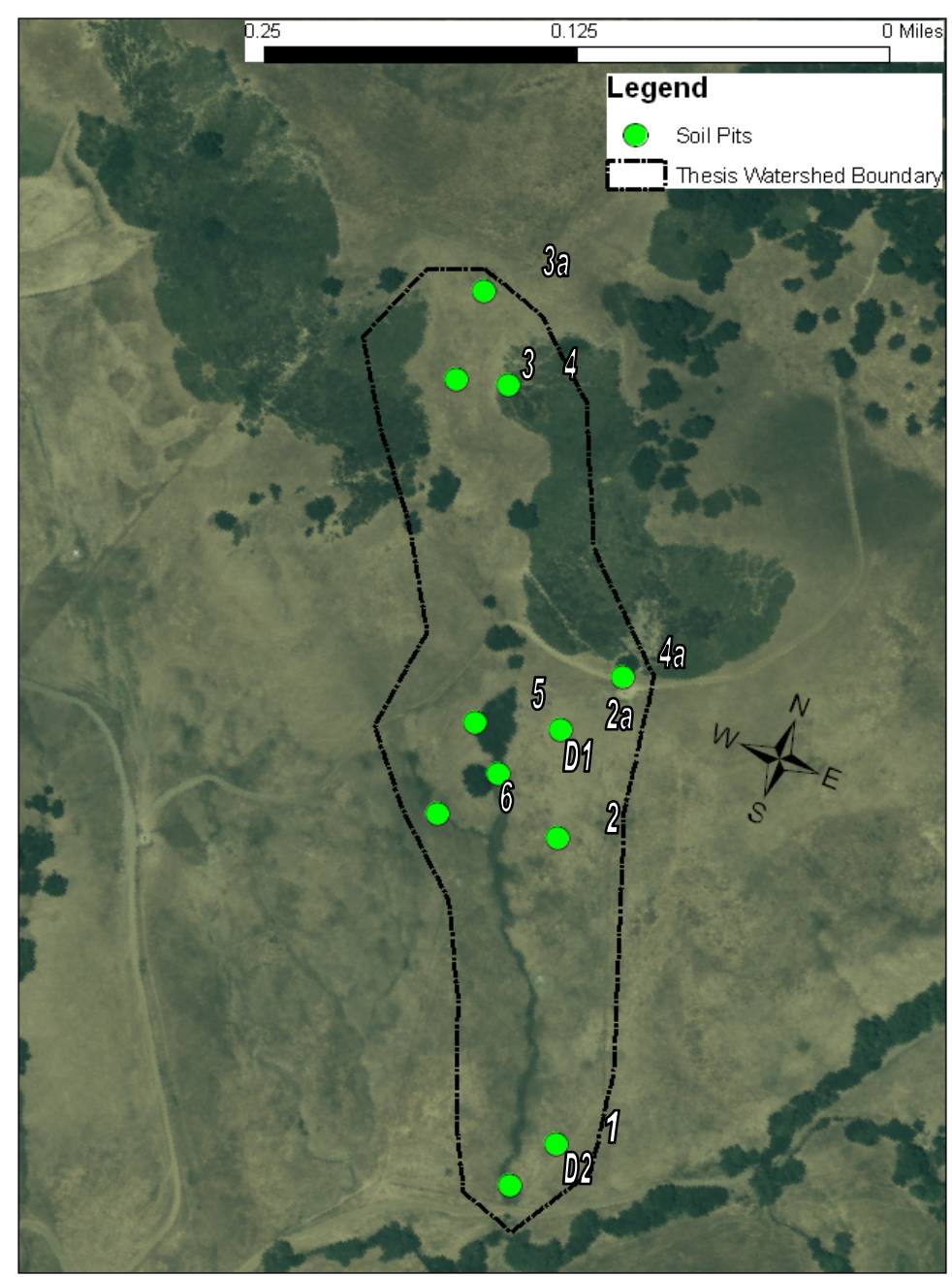

Figure 4-1: Thesis site showing the soil pit locations (created in ArcGIS version $6.2)$. 


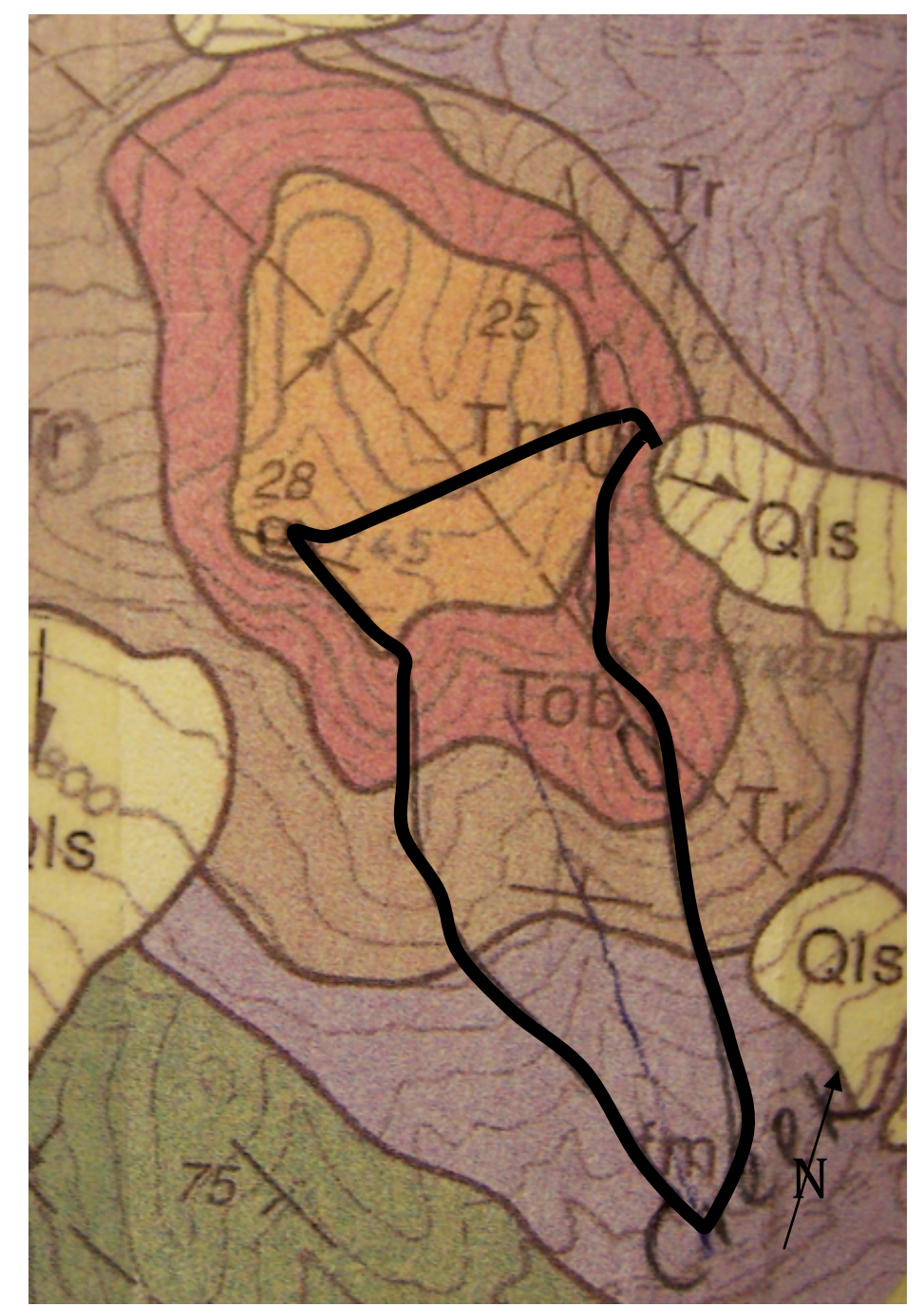

Figure 4-2. Geology of the watershed site (figure scale: $6.35 \mathrm{~cm}$ equals $0.6 \mathrm{~km})$. The watershed boundary is shown in black. Legend as follows: Qls=Landslides, landslide rubble; Tml=Monterey shale, marine biogenic, lithified, Miocene aged, shale, thin-bedded, platy siliceous to soft, fissile, phosphatic, cream-white weathered, contains thin, hard layers and concretions of yellowishgray dolomite; Tob=Obispo Formation, extrusive volcanic rocks, late to early Miocene aged (Relizian, upper Saucesian), basalt and diabase; $\mathrm{Tr}=$ Rincon shale, marine clastic, early Miocene aged (Saucesian-Zemorian stages), clay shale/claystone, gray, crumbly, massive; $\mathrm{fm}=$ Franciscan assemblage, pervasively sheared, slightly metamorphosed marine sedimentary and mafic volcanic rocks, mélange of claystone, graywacke, and blocks of other Franciscan rocks. Figure adapted from DF-129 Geology of San Luis Obispo Quadrangle (Dibblee, 2004). 
The bedrock geology onsite consists of Monterey Formation and Rincon shale, feldspathic greywacke of the Franciscan Melange, and diabase intrusions. At the study site, the Monterey Formation has thin dolomite concretions, an observation which is supported by the x-ray diffraction patterns. The graywackes are feldspathic, and consist predominantly of K-feldspars. There is evidence of landslides occurring on this site as sample site 1 has a lithologic discontinuity in the soil profile.

Studies have shown that watersheds underlain by sedimentary rock release higher concentrations of metals, nutrients and suspended sediment than watersheds underlain by igneous rock. A similar formation in California called the Monterey Formation (mostly sedimentary rock) has been shown to be a source of phosphate loadings (Bisson et al., 1987; Egli et al., 2008; Horowitz and Elrick, 1987; Richards, 1982; Trefry and Metz, 1985; Yoon and Stein, 2008). Since mostly sedimentary materials underlie this site, it has the potential to contribute a significant source of phosphate via suspended sediments and therefore may be a risk for water quality in surrounding waters. However, due to a drought year during the time when this study was conducted, an analysis of the water onsite was not possible.

\section{Petrographic Microscope THIN SECtion RESUlts}

The purpose of thin section analysis was to observe the minerals that constitute the parent rocks, and thereby determine the weathering sequences. In subsequent sections the clay minerals are identified on-site, this portion of my thesis will portray the minerals in the sand and silt fractions of the soils, which are 
inherited from the parent materials. While the percentages of the minerals were not quantified, most were identified. X-ray diffraction was also completed on the soil profiles to portray the minerals found in all particle size classes, and the minerals present are identified in subsequent sections.

The Goldich mineral stability series illustrates an arrangement of primary minerals in sequence from the most resistant to weathering to the least resistant to weathering. The sequence is basically the opposite of the Bowen's reaction series which shows the crystallization temperatures of common igneous minerals. The Goldich sequence indicates that the most resistant mineral is quartz, followed by muscovite, K-feldspars, biotite, Na-plagioclase, hornblende, augite, Ca-plagioclase, followed by the least resistant to weathering, olivine (Lynn et al., 2008). By identifying which minerals are present in the soils at the study site, weathering sequences can be established and the age of the soils can be roughly estimated. Knowing the minerals and weathering sequences will enable connections to be made between mineralogy/parent material and dispersivity, which, in turn, may provide insight regarding erosion and sedimentation rates.

The shale parent material at the study site (Fig. 4-3) consists of minerals having a preferential orientation, likely as a consequence of deposition and burial. It is evident that some of the shales on site are calcareous because they effervesce when hydrochloric acid is applied to the rock specimens. Also, calcite and dolomite minerals were identified in the thin sections. Goethite oxyhydoxide (iron oxide) lines the pore spaces in the shale (Fig. 4-3), which indicates 
weathering of minerals in the parent material. Quartz, mica and feldspars were also identified in this specimen, but most of the grains in the shale were too small to identify by petrographic microscopy.

Franciscan shale is typically present as thin seams between much thicker layers of graywacke, and at the study site there is petrographic evidence indicating this association of rock types. Mineralogically, the Franciscan shales are similar to Franciscan graywackes: they have a high proportion of angular minerals and rock fragments and only a small clay mineral fraction. The minerals that are common include quartz, feldspar, fine-grained chlorite, mica, sericite, some kaolinite, vermiculite, montmorillonite, orthoclase (with some occurrences of conversions to muscovite) and authigenic pyrite (Bailey, et al., 1964).

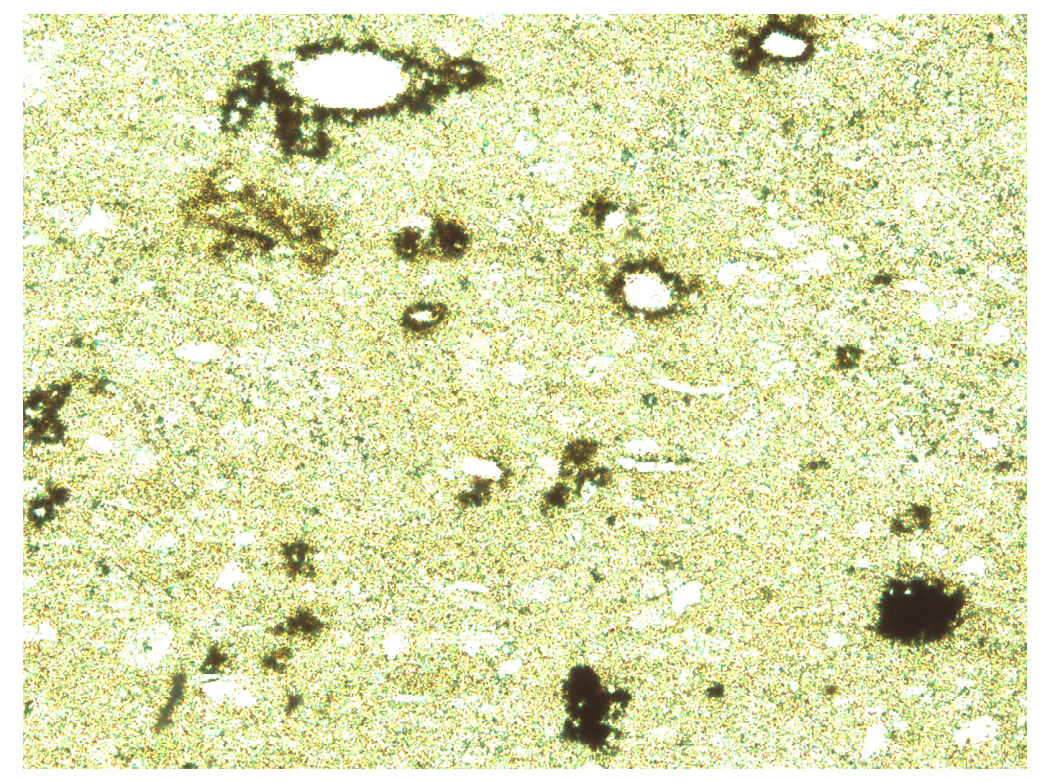

Figure 4-3: Petrographic thin-section (shown at 40x), portraying the Monterey Formation parent materials onsite. Pore spaces are lined with goethite iron oxides.

The diabase parent material onsite is highly weathered (Fig. 4-4 and 45). Highly weathered pyroxene (augite), quartz and biotite are present. 
There are also pieces of plagioclase showing albite twinning (Fig. 4-4 and 45) that are randomly arranged. The diabasic composition is the least common greenstones found in the Franciscan mélange. The diabasic texture that is usually found typically consists of plagioclase and augite as the dominant minerals present. Typically there are chlorites, plagioclases, pyroxenes (augite is the most common), magnetite, ilmenite, leucoxene and sphene (Bailey, et al., 1964).

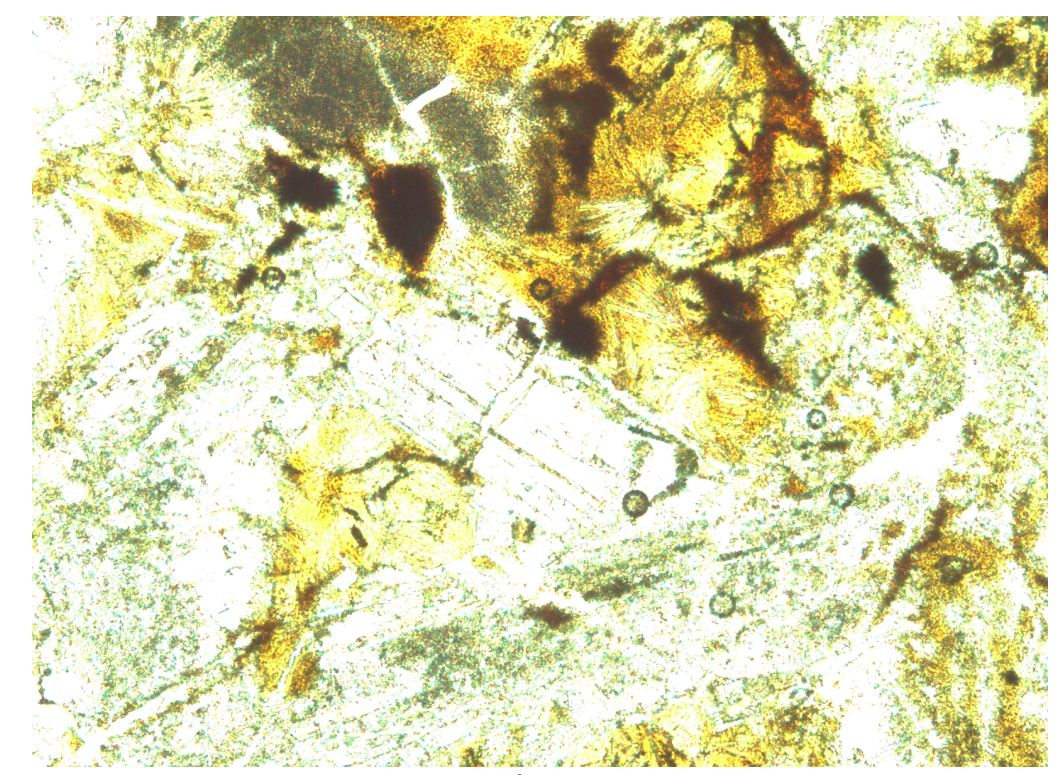

Figure 4-4: Petrographic thin-section (plane polarized light, shown at 40x) showing the diabase parent material onsite, which has highly weathered pyroxenes. 


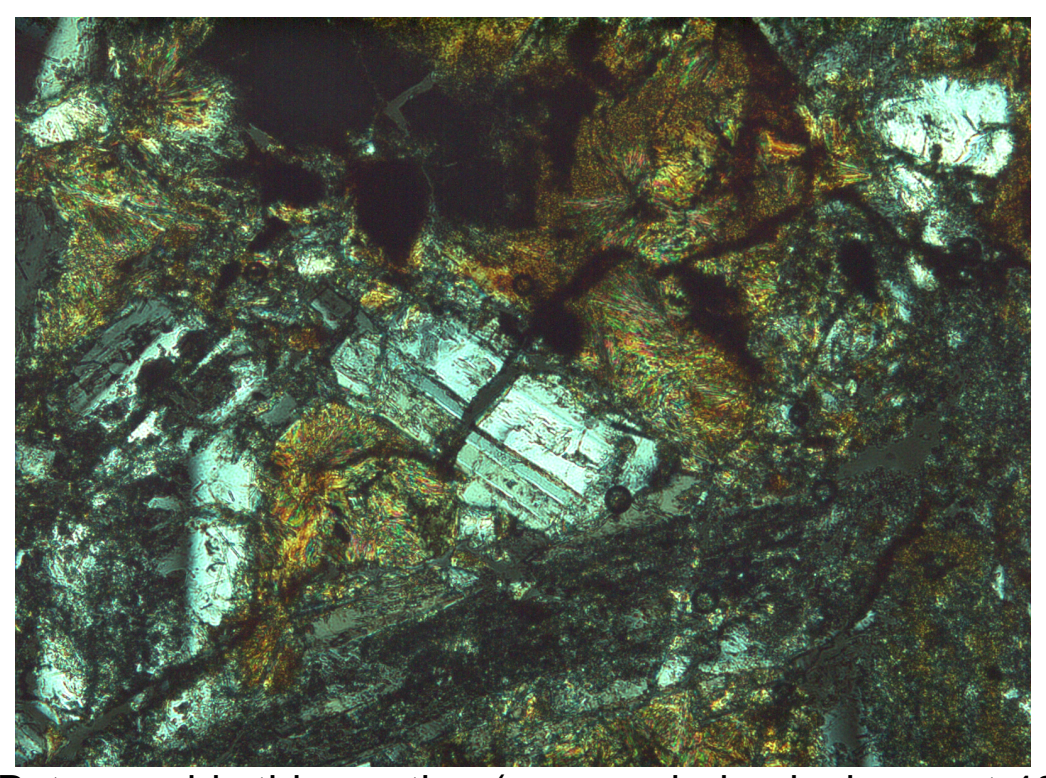

Figure 4-5: Petrographic thin-section (cross polarized, shown at 40x) showing the diabase parent material onsite, which has highly weathered pyroxenes.

The feldspathic greywacke (Fig. 4-6 and 4-7) is a typical Franciscan mélange greywacke specimen. Greywacke is the most abundant rock type in the Franciscan complex, therefore, it is not surprising that greywacke is a parent material at the study site (Bailey, et al., 1964). A large portion of the grains in the thin sections were K-feldspars. There are also quartz grains, biotite, augite, hornblende, plagioclase and shale lithics. Feldspathic graywackes in the Franciscan complex can have quartz, epidote, sphene, tourmaline, biotite, fine-grained chlorite, feldspar, augite, hornblende, hypersthene, black grains of shale, muscovite or biotite, calcite, albite and laumonite (Bailey, et al., 1964). 


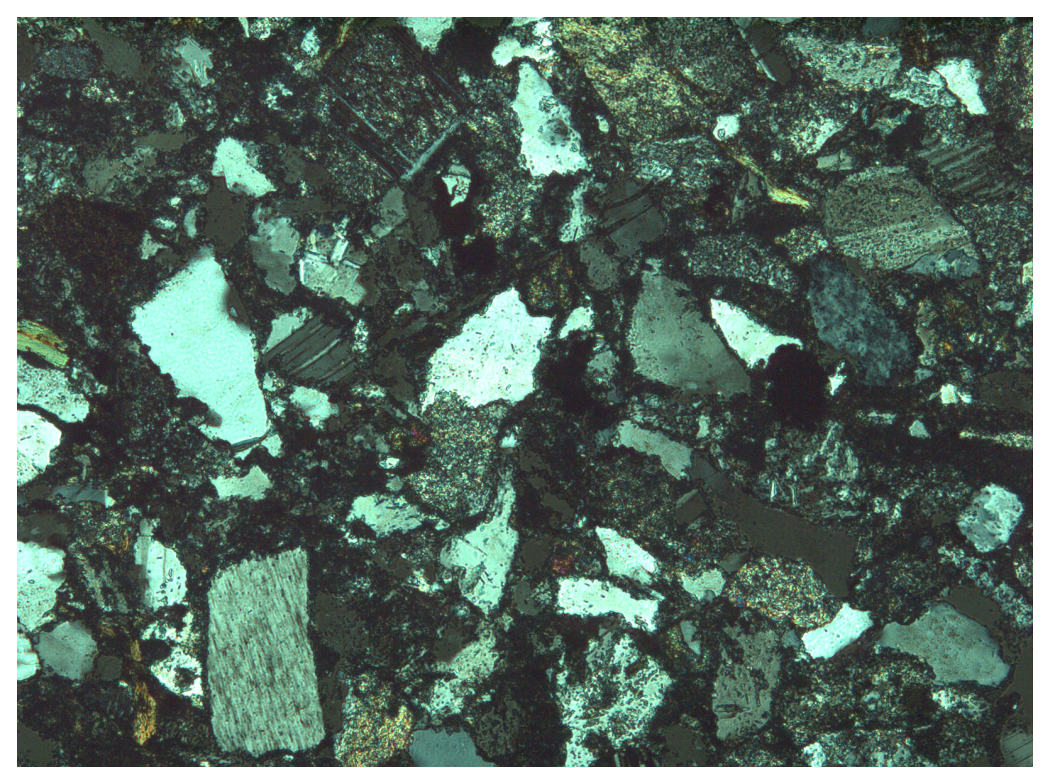

Figure 4-6: Petrographic thin-section (cross polarized, shown at 40x) showing the feldspathic greywacke onsite.

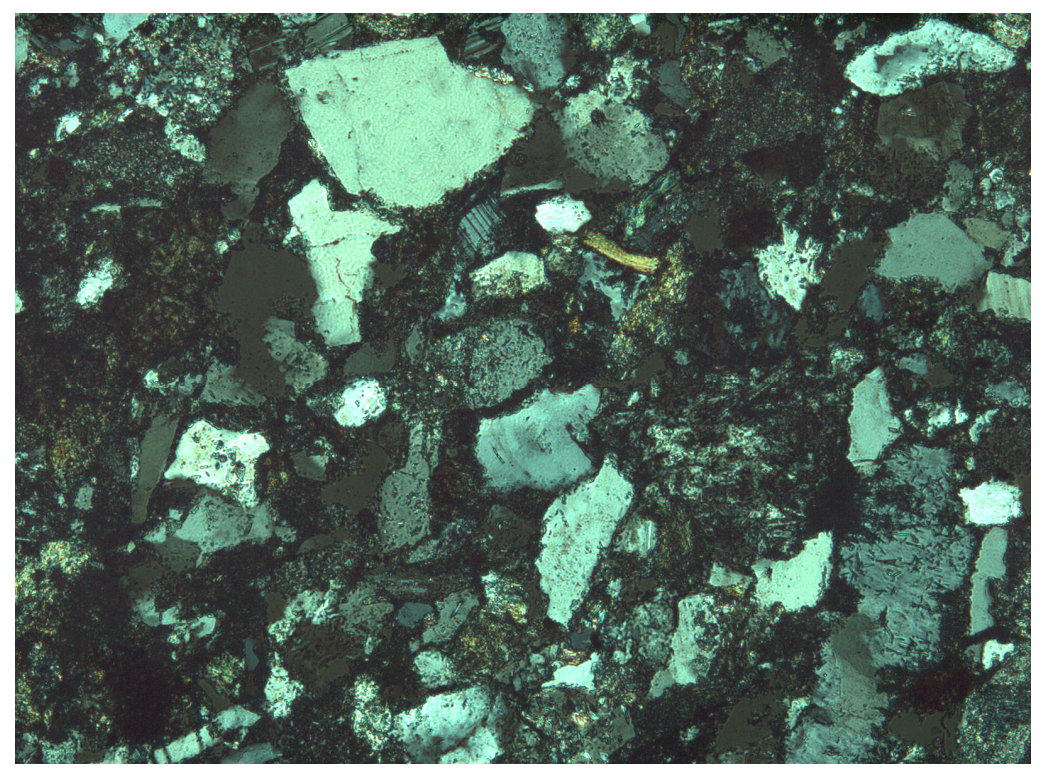

Figure 4-7: Petrographic thin-section (cross polarized, shown at 40x) showing a different view of the feldspathic greywacke onsite.

\section{DISPERSION BEHAVIOR}

The dispersion ratios were calculated by dividing the Na-dispersed particle size analysis samples silt fraction $(0.005 \mathrm{~mm})$ by the naturally dispersed soil samples silt fraction $(0.005 \mathrm{~mm})$. Therefore, the dispersion samples with the 
lowest ratios are the most dispersive because their behavior is closest to the $\mathrm{Na}$ dispersed soil samples. We can conclude then, that the most dispersive samples are from Pit 3a, 6, and D1 (Table 4-2). The dispersion rankings from most dispersive to least dispersive are therefore pits 3a (6.1), 6 (7.1), D1 (12), 4a (17), D2 (17.5), 2a (30). Hypothetically, the most dispersive soils are the most erodible soils and are most likely to contribute suspended sediment to surrounding streams.

\begin{tabular}{|c|c|}
\hline \multicolumn{2}{|c|}{ Table 4-2 A Horizon Dispersion Ratio } \\
\hline Site Number & Dispersion Ratio \\
\hline D1 & 12 \\
\hline D2 & 17.5 \\
\hline 2a & 30 \\
\hline 3a & 6.1 \\
\hline $4 a$ & 17 \\
\hline 6 & 7.1 \\
\hline
\end{tabular}
behaves.

*Dispersion Ratio $=$ the lower the number, the more dispersive the soil

All of the sites had moderate to high dispersion ratios because of the smectite minerals present. Relatively high dispersion ratios are close to 0 because dispersion is normalized to a Na-dispersed soil, and the Na-dispersed soil term is in the numerator of the ratio. A rating of 0 means the soil is extremely dispersive, whereas a rating of 100 means that the soil is not dispersive at all. As discussed in chapter one, smectites have high dispersion tendencies, indicating that sites high in smectite minerals will be more susceptible to erosion than sites with other clay minerals. Surprisingly, site 6 has a high dispersion ratio even though it technically had no smectite present. One explanation for this result is that the chlorite intermediate weathering product taking on characteristics of smectite minerals and acting more like hydroxy-interlayered 
smectite. The drainageways have moderate dispersion ratios compared to the other sites. Overall, this site is a concern for erosion and has the potential to contribute significantly to suspended sediment in surrounding surface waters if not managed correctly.

\section{MINERALOGY ANALYSIS}

The site 2a sample has smectite and mica in the clay mineral fraction (Fig. 4-8). Both dioctahedral and trioctahedral minerals are present in the diffraction patterns. Mica in the clay fraction is usually identified as illite, and is dioctahedral. Biotite is the most common trioctahedral mica and the most common dioctahedral mica is muscovite. However, the mica in the studied soils is most likely illite because biotite weathers to vermiculite and muscovite weathers to kaolinite (Thompson and Ukrainczyk, 2002). Since neither vermiculite nor kaolinite are found in the clay fraction of the soil at site $2 \mathrm{a}$, it would appear that illite is weathering to smectites at site $2 \mathrm{a}$, however, the $\mathrm{x}$-ray diffraction patterns for the $\mathrm{Cr}$ horizon show only smectite. Illite can be formed from feldspars and since there is a high feldspar content in the parent material and soil, it is possible that the weathering sequence has feldspar forming illite, but illite could also be formed from a source of potassium at the surface horizon. This area does not have a history of pesticide or fertilizer application, but there could be potassium originating from plant remains. The smectite is most likely inherited from the parent material and the illite-like mineral is forming at the surface horizon as biocycled potassium. 


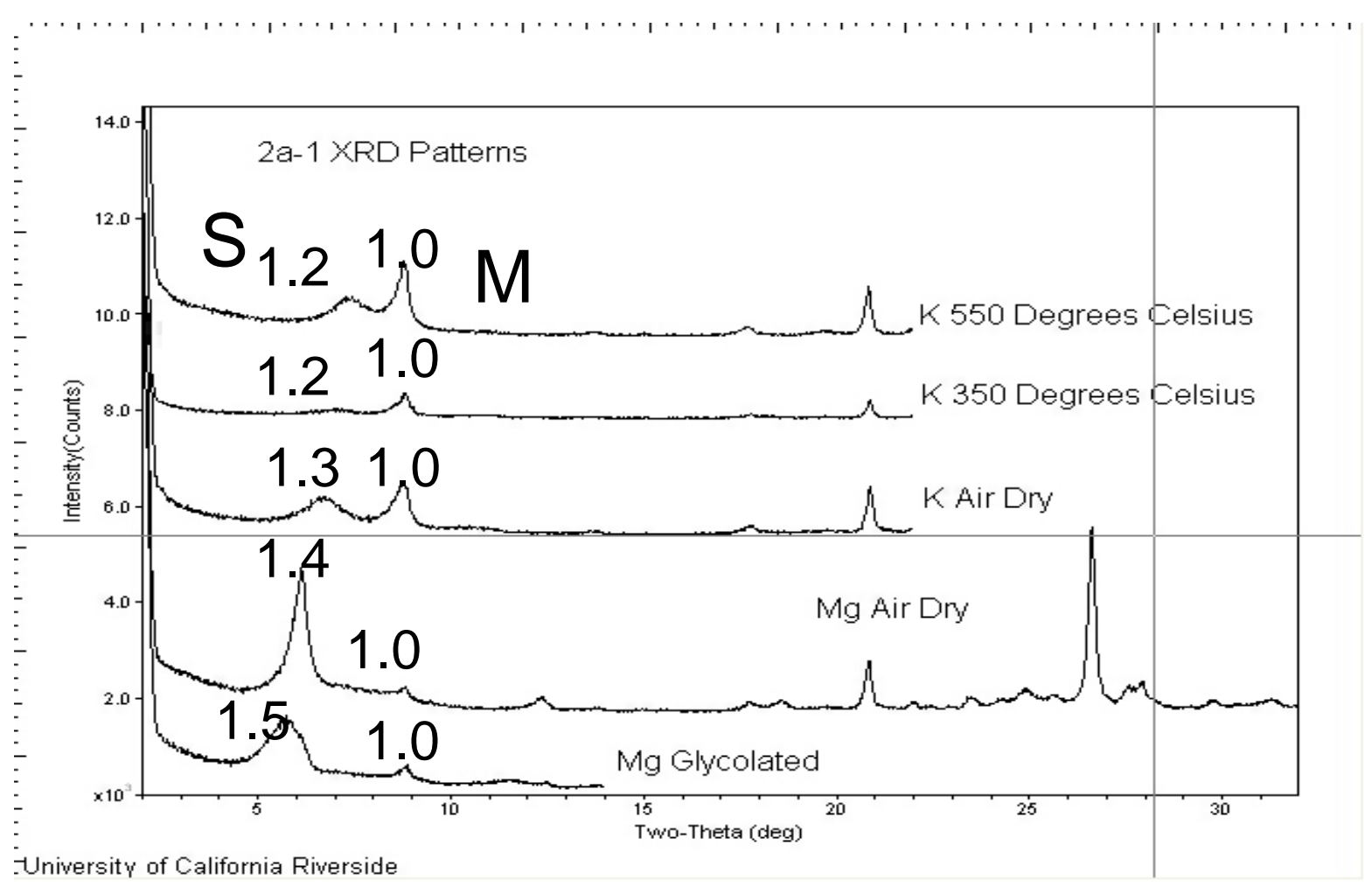

Figure 4-8: X-ray diffraction pattern for the clay fraction of the A horizon from site 2a. $\mathrm{S}=$ Smectite, $\mathrm{M}=$ Mica.

The smectite at site $2 \mathrm{a}$ is trioctahedral, and trioctahedral smectites are usually formed from chlorite (Barnhisel, 1977). Since chlorite can be found in shale parent materials in the Franciscan complex, this likely is the source of the trioctahedral smectite.

Packed powder mounts were made for the A horizon (all particle size fractions) as well, and revealed quartz, dolomite, microcline, anorthite, orthoclase, and plagioclase. The parent material for this site is the Monterey Formation (siliceous shale). High dispersion and Cation Exchange Capacity (CEC) rates are expected in this soil because it has smectite minerals present. This soil should have the ability to adsorb large amounts of metals and nutrients. 
Owing to its potential to be dispersive and erode, it may contribute to sediment loading.

Site 3a has smectite and illite present in the clay fraction of the soil (Fig. 49). There are dioctahedral and trioctahedral minerals present in the $x$-ray diffraction patterns.

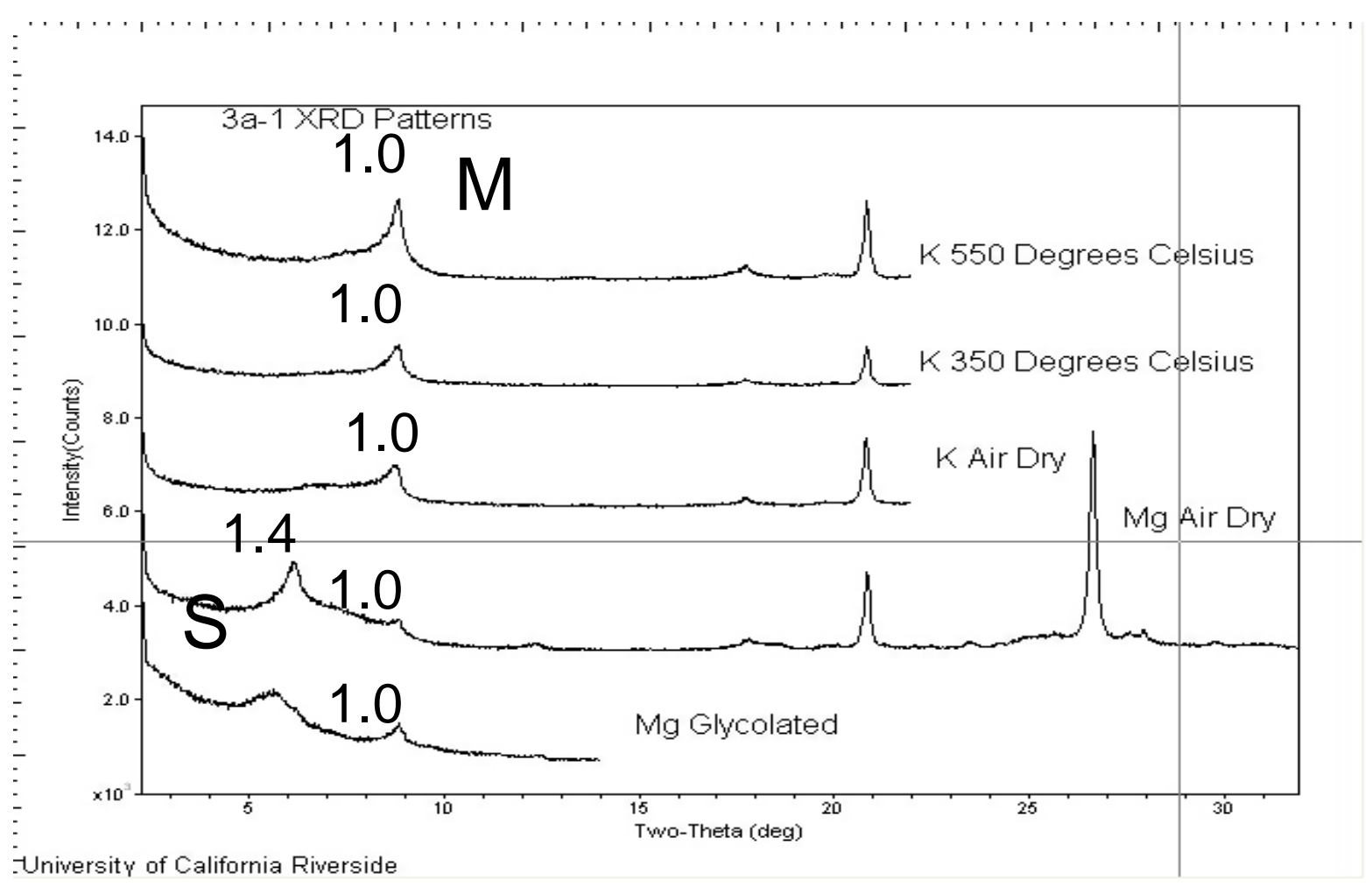

Figure 4-9: X-ray diffraction pattern for the clay fraction of the A horizon from site 3a. $S=S m e c t i t e, M=$ Mica.

Packed powder mounts were made for the A horizon (all particle size classes) of soil site $3 a$ as well and revealed quartz and orthoclase. The parent material for site 3a is Rincon Shale. No Cr horizon was reached at this site, so no conclusions were made regarding the origin of the illite minerals.

High dispersion and CEC rates from site $3 a$ are expected because it has smectite minerals present. This soil should have the ability to adsorb large 
amounts of metals and nutrients. Owing to its potential to be dispersive and erode, it may contribute to sediment loading.

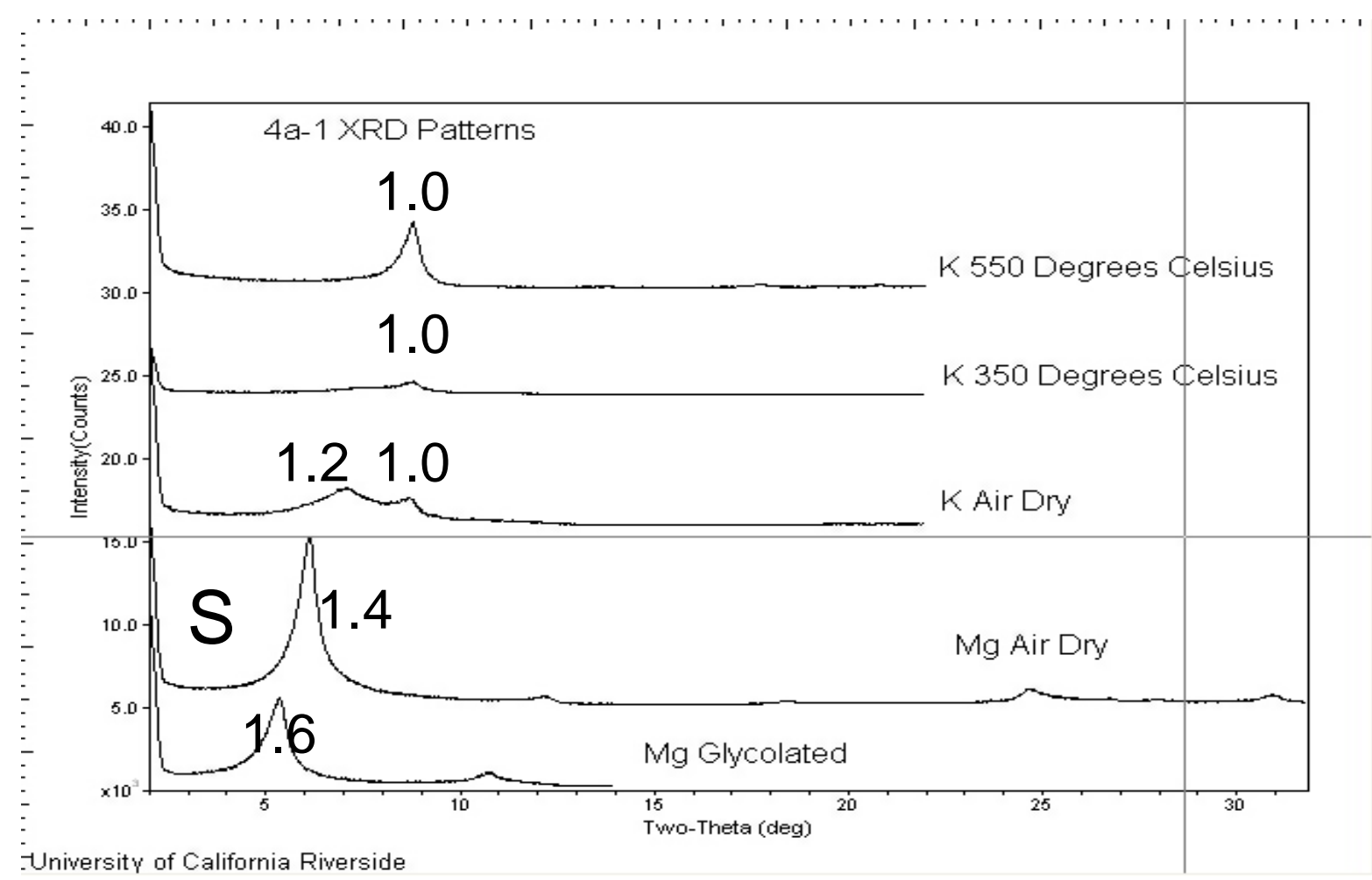

Figure 4-10: X-ray diffraction pattern for the clay fraction of the A horizon from site 4 a. $S=S$ mectite.

Site 4a portrays a typical smectite XRD pattern and little else in the clay fraction (Fig. 4-10). High dispersion and CEC rates from site $4 a$ are expected because it has smectite minerals present. This soil should have the ability to adsorb large amounts of metals and nutrients. Owing to its potential to be dispersive and erode, it may contribute to sediment loading.

In the clay fraction of site 6 (Fig. 4-11) there is mica, chlorite and what appears to be an intermediate weathering product of chlorite. The x-ray diffraction patterns reveal that both dioctahedral and trioctahedral minerals are 
present. The dioctahedral mica is most likely illite, which is probably forming in the surface horizon by incorporating potassium obtained from decomposition of plant material, or by incorporating potassium received from the weathering of the K-feldspars in the parent material. The trioctahedral chlorite is creating an intermediate weathering product that is weathering to trioctahedral smectite (Barnhisel, 1977).

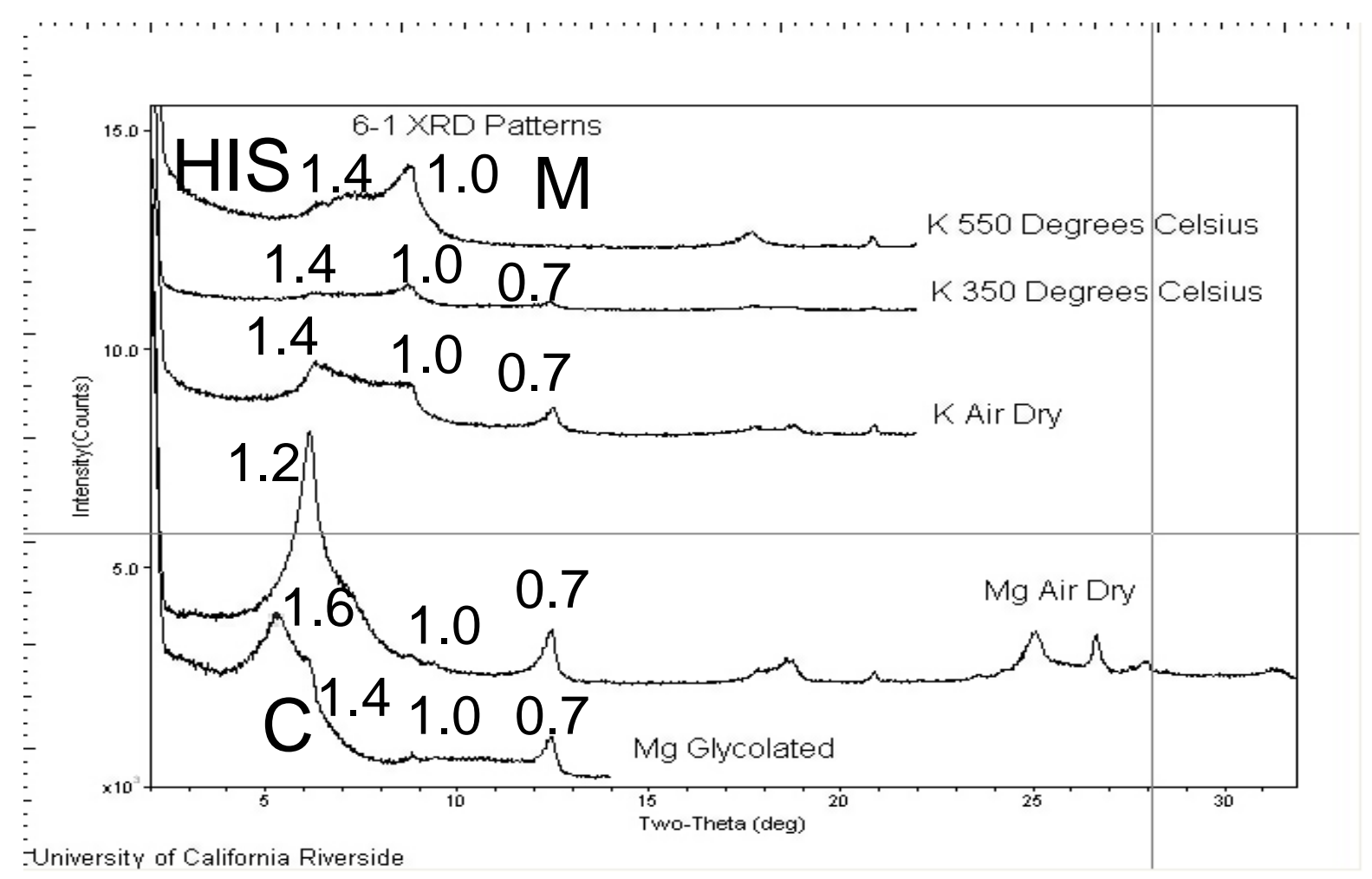

Figure 4-11: X-ray diffraction pattern for the clay fraction of the $A$ horizon from site 6. $\mathrm{M}=$ Mica, $\mathrm{C}=\mathrm{Ch}$ lorite, $\mathrm{HIS}=$ Intermediate weathering product from Chlorite/Hydroxy-interlayered smectite.

Packed powder mounts were made for the A horizon (all particle size classes) of site 6 as well, and XRD analysis reveals the presence of quartz, augite, dolomite and calcite. The parent material for this particular site location is 
greywacke, and the dolomite and calcite from the shale interbeds within the greywacke (Bailey, et al., 1964).

High dispersion and CEC rates from site 6 are expected because it has intermediate weathering products originating from chlorite/hydroxy-interlayered smectite. While chlorite typically has low CEC values, intermediate weathering products tend to increase in CEC values and take on characteristics similar to smectite. Despite the fact that this site does not have smectite, it may still pose the same amount of risk as the other sites that do because of the nature of the intermediate weathering products. Sedimentation rates and erosion are still risk factors from site 6 .

D1 and D2 (Fig. 4-12 and 4-13) portray the soils in the drainageway that divides the site. The drainageway soil contains evidence of minerals derived from all the soil sites. It portrays the transformation of chlorite to smectite with the HIS-like material present, as well as smectite and micas. Again, the mica that is being discovered is most likely illite formed in the A horizon and not from the parent materials. An overall summary of the soil mineralogy on site is shown in Table 4-3. 


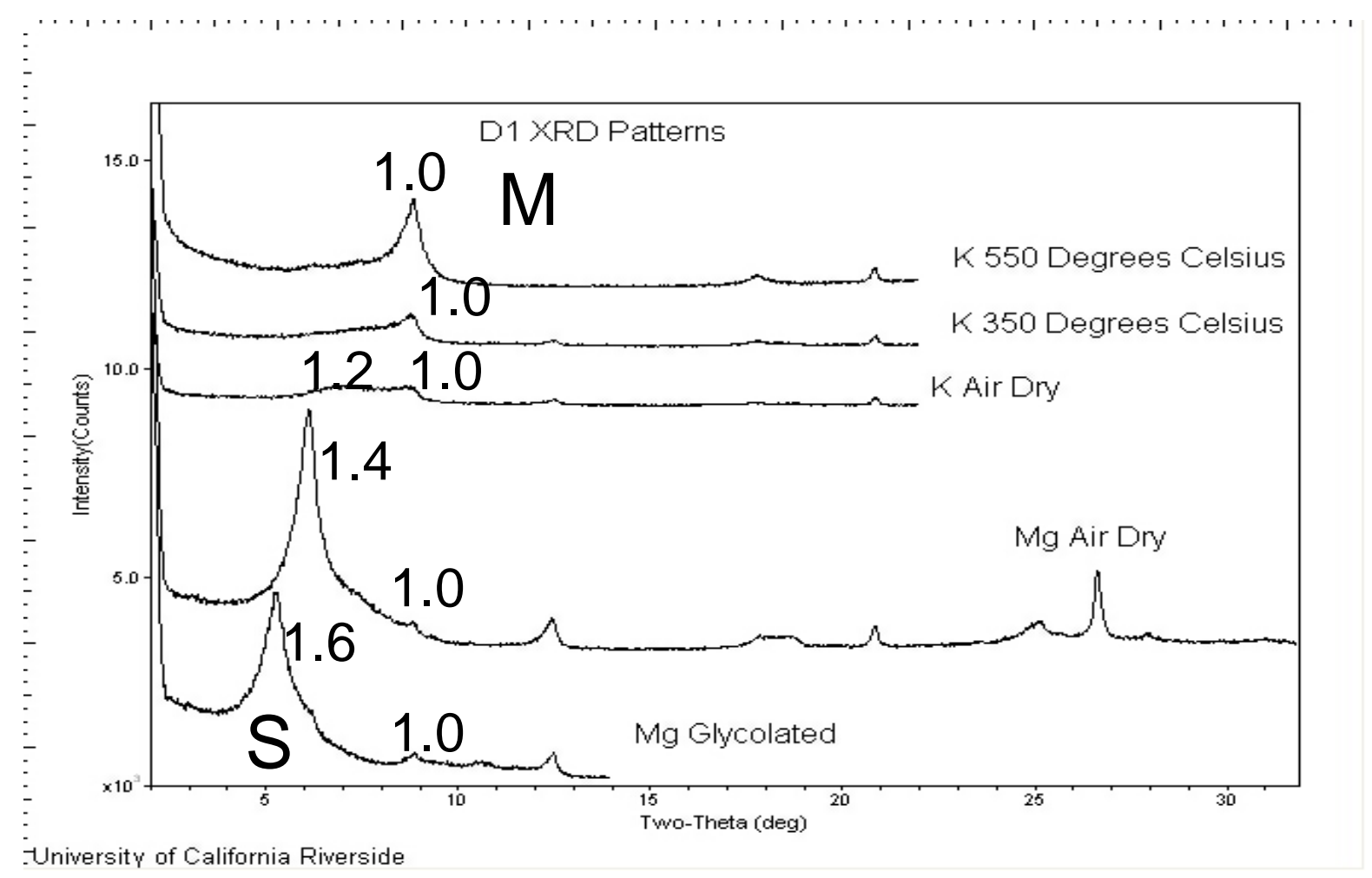

Figure 4-12: X-ray diffraction pattern for the clay fraction of the A horizon from the drainageway site D1 (upstream of site D2). M=Mica, $S=S m e c t i t e$. 


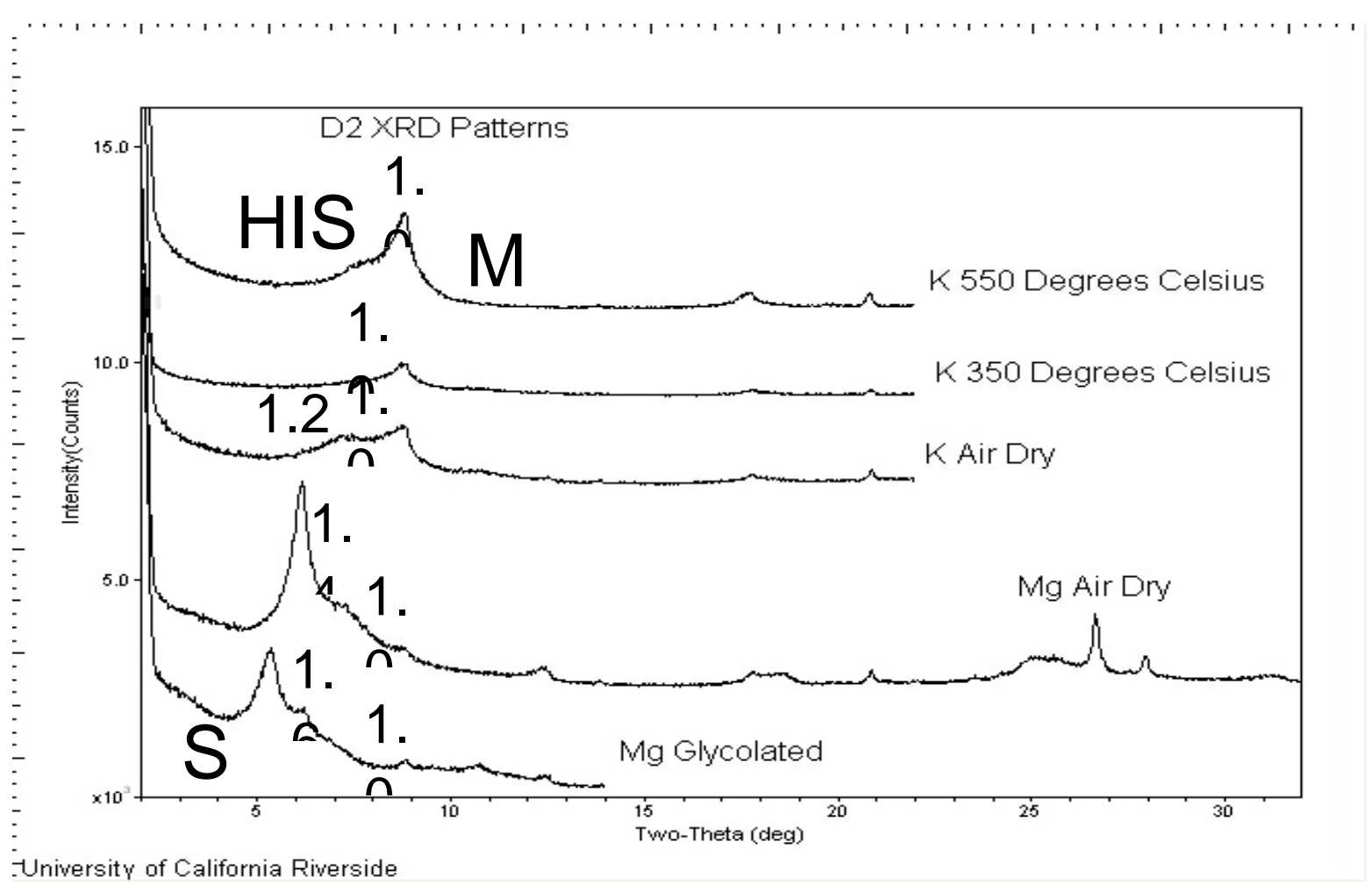

Figure 4-13: X-ray diffraction pattern for the clay fraction of the A horizon from the drainageway site $\mathrm{D} 2$.

D1 appears to be nearly identical to the clay mineralogy of sites $2 a, 3 a$, and $4 a$ (Table 4-3). D1 is the drainageway sample site that is located in the middle of the watershed, and is closest to sites $2 a, 3 a$, and $4 a$. It is not unexpected that this site would have mineralogy similar to these sites because of their proximity to the drainageway, and because all of these sites drain directly to D1. The similar mineralogy of site D1 and the sites above and around it indicate that suspended sediment is indeed carried in overland flow, and that the clay minerals from these surrounding sites are being delivered into the site's drainageways, and therefore the surrounding waterways. 
The soil of the D2 site appears to also have identical mineralogies to the soils of the $2 a, 3 a$ and $4 a$ sites, as well as contributions from the soil of site 6 (Table 4-3). Since site D2 is at the bottom of the watershed and at the bottom of the drainageway, this indicates that the overland flow occurring onsite is enough to transport minerals from the top of the watershed to the bottom. Therefore, the study site is an active nonpoint source contributor to suspended sediment in the surrounding surface waters. 


\begin{tabular}{|c|c|c|c|}
\hline \multicolumn{4}{|c|}{ Table 4-3: Mineral Analysis of On-Site Soils } \\
\hline Pit & Horizon & Clay Fraction Minerals & Sand and Silt Fraction Minerals \\
\hline D1 & A & Smectite and Illite & $\begin{array}{c}\text { Orthoclase, Quartz, Anorthite, } \\
\text { Microcline }\end{array}$ \\
\hline D2 & A & $\begin{array}{l}\text { Smectite, Illite and an } \\
\text { intermediate weathering } \\
\text { product of Chlorite/Hydroxy- } \\
\text { interlayered smectite }\end{array}$ & $\begin{array}{c}\text { Quartz, Plagioclase, } \\
\text { Orthoclase, Anorthite, Dolomite, } \\
\text { Calcite, Microcline }\end{array}$ \\
\hline \multirow[t]{2}{*}{$2 a$} & A & Smectite and Illite & $\begin{array}{c}\text { Quartz, Dolomite, Microcline, } \\
\text { Anorthite, Orthoclase, } \\
\text { Plagioclase }\end{array}$ \\
\hline & C & Smectite & Not determined \\
\hline \multirow{2}{*}{$3 a$} & $A$ & Smectite and Illite & Quartz, Orthoclase \\
\hline & $\mathrm{C}$ & Not determined & Quartz, Calcite, Plagioclase \\
\hline \multirow{2}{*}{$4 a$} & $A$ & Smectite & $\begin{array}{c}\text { Plagioclase, Anorthite, Augite, } \\
\text { Enstatite, Quartz }\end{array}$ \\
\hline & C & Smectite & Anorthite, Augite \\
\hline \multirow[t]{2}{*}{6} & A & $\begin{array}{c}\text { Chlorite, Illite and an } \\
\text { intermediate weathering } \\
\text { product of Chlorite/Hydroxy- } \\
\text { interlayered smectite }\end{array}$ & Quartz, Dolomite or Calcite \\
\hline & C & Not determined & Albite, Quartz \\
\hline
\end{tabular}




\section{CATION EXCHANGE CAPACITY}

Smectites and illites are known for having high CEC values, usually in the ranges of $47-150 \mathrm{cmolc} / \mathrm{kg}$ for smectite, and 15 to $40 \mathrm{cmolc} / \mathrm{kg}$ for illite (ReidSoukup and Ulery, 2002; Thompson and Ukrainczyk, 2002). It should be noted however, that illite's CEC values can be influenced by associated smectite particles (Thompson and Ukrainczyk, 2002). The lowest cation exchange value came from site $3 a$, which surprisingly had a very high dispersion behavior. I attribute this to the organic carbon content (Table 4-6). Surprisingly, site 6 has one of the highest CEC's. Usually chlorites have very low CEC values, however, the CEC values for intermediate products from chlorite have higher CEC values than pure chlorite, so this CEC value is more evidence that this intermediate product is acting more like a smectite mineral (Kohut and Warren, 2002). This is another indication that this mineral is a part of a chlorite-to-smectite weathering sequence. 


\begin{tabular}{|c|c|}
\hline \multicolumn{2}{|c|}{ Table 4-5: Soil Cation Exchange Capacity Values } \\
\hline Pit & $\begin{array}{c}\text { Cation Exchange Capacity Value } \\
\text { (cmolc/kg) }\end{array}$ \\
\hline D1 & 40.99 \\
\hline D2 & 40.43 \\
\hline 2a & 50.77 \\
\hline 3a & 37.14 \\
\hline $4 a$ & 46.97 \\
\hline 6 & 49.24 \\
\hline
\end{tabular}

\begin{tabular}{|c|c|c|c|}
\hline \multicolumn{4}{|c|}{ Table 4-6: Organic Carbon Content } \\
\hline Site Location & Nitrogen & Carbon & \% Organic Matter \\
\hline D1 & 0.161 & 1.702 & 3.404 \\
\hline D2 & 0.136 & 1.469 & 2.938 \\
\hline 2a-1 & 0.159 & 1.510 & 3.020 \\
\hline 3a-1 & 0.276 & 2.333 & 4.666 \\
\hline 4a-1 & 0.111 & 1.134 & 2.268 \\
\hline 6-1 & 0.094 & 1.140 & 2.280 \\
\hline
\end{tabular}

\section{CONCLUSION}

This site has the potential to be a nonpoint source of pollution. The high CEC values onsite indicate that the soil is adsorbing the cations and acting as a filtering agent instead of a carrying agent. However, once soil enters surface waters, it no longer acts as a filtering agent. Instead, the soil conveys contaminants. The dispersion rates established for and minerals identified within the studied soils indicate highly erosive soils. This area has the ability, if not managed properly, to contribute a significant amount of suspended sediment to surrounding surface waters. 
The dispersive and highly erodible soils could be held onsite and kept out of surface waters if the area remains properly vegetated. Currently, this land is used for recreational hiking, cycling and livestock grazing. The current management style maintains a rotational grazing program and allows for plenty of vegetation cover and helps minimize soil compaction. This insures that little soil will erode into the nearby surface waters. It is recommended that the management close the area to the public (especially to cyclists) during the wet season. Furthermore, animal activity should be minimized onsite during the wet season to insure that the trails and paths do not become compacted.

Sediment loading from eroding soil is a major concern for surrounding surface water. The contaminant that would most likely be a problem from this area is phosphorus. While this study was unable to obtain water samples due to a drought year, other studies have shown that watersheds underlain by sedimentary rock yield higher concentrations of metals, nutrients and suspended sediment when compared to watersheds underlain by igneous rock. The Monterey Formation, which is present in the study area, has been shown to be a source of phosphate loadings (Bisson et al., 1987; Egli et al, 2008; Horowitz and Elrick, 1987; Richards, 1982; Trefry and Metz, 1985; Yoon and Stein, 2008). The high CECs in study area soils indicate that the phyllosilicates will bind with phosphates from the parent material, and are capable of being carried into the surrounding surface waters as suspended sediment.

There appears to be an inverse relationship between dispersion and cation exchange capacity onsite (Table 4-7). Smectite is the most dispersive 
mineral, but there is no consistent trends regarding the dispersivity of different minerals in the soils of the study area. This is because the population/sample size is too small and there are mixed mineralogies across the site making it difficult to identify any trends. Texture and organic carbon appear to be confounding variables as well. It can be concluded that the dispersive properties of soils at the study site make them susceptible to erosion, and that because of the high CECs, the eroded material has the potential to carry contaminants into surface waters. 


\begin{tabular}{|c|c|c|c|c|}
\hline $\begin{array}{l}\text { Site } \\
\text { Number }\end{array}$ & $\begin{array}{l}\text { Texture \& } \\
\text { Clay \% (A } \\
\text { Horizon) }\end{array}$ & Clay Mineralogy & $\begin{array}{l}\text { Dispersion } \\
\text { Ratio }(\mathrm{g} / \mathrm{L})\end{array}$ & $\begin{array}{l}\text { CEC Value } \\
(\mathrm{cmol} / \mathrm{kg})\end{array}$ \\
\hline D1 & $\begin{array}{l}\text { Loam (22 } \\
\% \text { Clay) }\end{array}$ & Smectite and mica & 12 & 40.99 \\
\hline D2 & $\begin{array}{l}\text { Loam }(25 \% \\
\text { Clay) }\end{array}$ & $\begin{array}{l}\text { Intermediate weathering } \\
\text { product from } \\
\text { chlorite/hydroxy- } \\
\text { interlayered smectite, mica } \\
\text { and smectite }\end{array}$ & 17.5 & 40.43 \\
\hline $2 a$ & $\begin{array}{l}\text { Loam }(23 \% \\
\text { Clay) }\end{array}$ & Smectite and mica & 30 & 50.77 \\
\hline $3 a$ & $\begin{array}{l}\text { Silty Clay } \\
(43 \% \text { Clay })\end{array}$ & Smectite and mica & 6.1 & 37.14 \\
\hline $4 a$ & $\begin{array}{l}\text { Sandy } \\
\text { Loam (10\% } \\
\text { Clay) }\end{array}$ & Smectite & 17 & 46.97 \\
\hline 6 & $\begin{array}{l}\text { Clay }(45 \% \\
\text { Clay) }\end{array}$ & $\begin{array}{l}\text { Intermediate weathering } \\
\text { product from } \\
\text { chlorite/hydroxy- } \\
\text { interlayered smectite, mica } \\
\text { and chlorite }\end{array}$ & 7.1 & 49.24 \\
\hline
\end{tabular}




\section{REFERENCES}

Arora, H.S., N.T. Coleman. 1979. The influence of electrolyte concentrations on flocculation of clay suspensions. Soil Sci. 127: 134-139.

Bailey, E.H., W.P. Irwin, and D.L. Jones. 1964. Franciscan and related rocks, and their significance in the geology of Western California. Bulletin 183 Calfornia Division of Mines and Geology, Sacramento, CA.

Barnhisel, R.I. 1977. Chlorites and Hydroxy Interlayered Vermiculite and Smectite. p. 331-356 In J.B. Dixon and S.B. Weed (eds.) Minerals in soil environments ( $1^{\text {st }}$ Edition). Soil Sci. Soc. Am. Book 1, Madison, WI.

Barthelmy, D. 2005. Mineral database [online]. Available at http://webmineral.com/ (verified 7 of March, 2009).

Batram, J., W.W. Carmichael, I. Chores, G. Jones, and O.M. Skulberg. 1999. Toxic Cyanobacteria in water: A guide to their public health consequences, monitoring and management [online]. Available at http://www.who.int/water_sanitation_health/resourcesquality/toxicyanbact/en/ (verified 15 of February, 2009).

Bisson, P.A., R.E Bilby, M.D. Bryant, C.A. Dolloff, G.B. Grette, R.A. House, M.L. Murphy, K.V. Koski, and J.R. Sedell. 1987. Large woody debris in forested streams in the Pacific Northwest: Past, present, and future. p. 143-190. In E.O. Salo and T.W. Cundy (eds.) Streamside management: Forestry and fishery interactions. Univ. of Washington Inst. Forest Res., Seattle, WA.

Borchardt, G. 1989. Smectites. p. 675-727 In J.B. Dixon and S.B. Weed. (eds.) Minerals in soil environments ( $2^{\text {nd }}$ Edition). Soil Sci. Soc. Am. Book 1, Madison, WI.

Calero, N., V. Barrón, and J. Torrent. 2008. Water dispersible clay in calcareous soils of Southwestern Spain. Catena 74: 22-30.

Country Studies. 2003. San Luis Obispo weather [online]. Available at http://countrystudies.us/united-states/weather/California/san-luis-obispo.htm (verified 9 of March, 2009).

Dibblee, Thomas W., Jr. 2004. Geologic map of the San Luis Obispo quadrangle, San Luis Obispo County, California. Dibblee Center Map \#DF-129, Santa Barbara Museum of Natural History, Santa Barbara, CA.

Dictionary. 2010. Drainageway definition [online]. Available at http://dictionary.reference.com/browse/drainageway (verified 27 of April, 2010).

Dixon, J.B. 1989. Kaolin and serpentine group minerals. p. 467-525. In Dixon, J.B. and S.B. Weed (eds.) Minerals in soil environments ( $2^{\text {nd }}$ Edition). Soil Sci. Soc. Am. Book 1, Madison, WI. 
Egli, M., C. Merkli, G. Sartori, A. Mirabella, and M. Plötze. 2008. Weathering, mineralogical evolution and soil organic matter along a Holocene soil toposequence developed on carbonate-rich materials. Geomorph. 97(3-4): 675-696.

ESRI GIS and Mapping Software. 2008. ArcGIS 6.2. ESRI, Redlands, CA.

European Synchrotron Radiation Facility. 2007. Following local adsorption sites through a surface chemical reaction: $\mathrm{CH} 3 \mathrm{SH}$ on $\mathrm{Cu}$ (111) [online]. Available at http://www.esrf.eu (verified 2 of February, 2009).

Fanning, D.S., V.Z. Keramidas, and M.A. El-Desoky. 1989. Micas. p. 551-634. In J.B. Dixon and S.B. Weed. (eds.) Minerals in soil environments $\left(2^{\text {nd }}\right.$ Edition). Soil Sci. Soc. Am. Book 1, Madison, WI.

Frenkel, H., G.J. Levy and M.V. Fey. 1992. Clay dispersion and hydraulic conductivity of clay-sand mixtures as affected by the addition of various anions. Clays Clay Min. 40: 515-521.

Gee, G.W., and D. Orr. 2002. Particle-size analysis. p. 255-293. In J.H. Dane and G.C. Topp (eds.). Methods of soil analysis part 4 physical methods. Soil Sci. Soc. Am., Inc., Madison, WI.

Goldberg, S., D. Suarez and R.A. Glaubic. 1988. Factors affecting clay dispersion and aggregate stability of arid-zone soils. Soil Sci. 146: 317-325.

Graham, R. Personal communication March 18, 2009. Univ. Riverside, Riverside, California.

Grim, R.E. 1968. Clay mineralogy. McGraw-Hill Book Co., Inc., New York, NY.

Harper, D. 1992. Eutrophication of freshwaters: Principles, problems and restoration. Chapman and Hall, New York, NY.

Hillel, D. 1998. Environmental soil physics. Academic Press, San Diego, CA.

Horowitz, A.A., and K.A. Elrick. 1987. The relationship of stream sediment surface area, grain size, and composition to trace element chemistry. Appl. Geochem., 2(4): 437-445.

Jackson, M.L. 1969. Soil chemical analysis - advanced course ( $2^{\text {nd }}$ edition). M.L. Jackson, Library of Congress Catalogue, U.S.A.

Klein, C. 2002. Mineral science (22 $2^{\text {nd }}$ Edition). John Wiley and Sons, Inc., New York, NY.

Kohut, C.K. and C.J. Warren. 2002. Chlorite. p. 531-554. In J.B. Dixon and D.G. Schulze (eds.). Soil mineralogy with environmental applications. Soil Sci. Soc. Am. Book 7, Madison, WI.

Koroncai, R., L. Linker, J. Sweeney, and R. Batiuk. 2003. Setting and allocating the Chesapeake Bay nutrient and sediment loads. EPA903-R-03-007. U.S. EPA, Chesapeake Bay Program Office, Annapolis, MD.

Lado, M., and M. Ben-Hur. 2004. Soil mineralogy effects on seal formation, runoff and soil loss. App. Clay Sci. 24: 209-224. 
Lynn, W., J.E. Thomas, and L.E. Moody. 2008. Petrographic microscope techniques for identifying soil minerals in grain mounts. p. 161-190. In A.L. Ulery and L.R. Drees (eds.) Mineralogical methods - Methods of soil analysis part 5. Soil Sci. Soc. Am., Madison, WI.

Moore, D.M., and R.C. Reynolds, Jr. 1989. X-ray diffraction and the identification and analysis of clay minerals. Oxford University Press, Oxford, New York.

Morro Bay National Estuary Program. 2009. Morro Bay national estuary program [online]. Available at www.mbnep.org (verified 3 March, 2009).

Osidele, O., W. Zeng and M.B. Beck. 2003. Coping with uncertainty: A case study in sediment transport and nutrient load analysis. J. Water Res. Plan. \& Manage. 129(4): 345-355.

Reid-Soukup, D.A., and A.L. Ulery. 2002. Smectites p. 467-500 In J.B. Dixon and D.G. Schulze (eds.). Soil mineralogy with environmental applications, book series 7. Soil Sci. Soc. Am. Madison, WI.

Richards, K. 1982. Rivers: form and process in alluvial channels. Methunen and Co., New York, NY.

Singer, A. 1994. Clay mineralogy as affecting dispersivity and crust formation in aridisols. p.37-46. In J.D. Etchevers (ed.) Transactions of the $15^{\text {th }}$ World Congress of Soil Science. Acapulco, Mexico. International Society of Soil Science and Mexican Society of Soil Science Vol. 8a. Commission VII. Acapulco, Mexico.

Soukup, D.A., L.R. Drees, and W.C. Lynn. 2008. Sampling soils for mineralogical analyses. p. 1-11. In A.L. Ulery and L.R. Drees (eds.) Mineralogical methods - Methods of soil analysis part 5. Soil Sci. Soc. Am., Madison, WI.

Sparks, D.L. 1995. Environmental soil chemistry. Academic Press, Inc. San Diego, CA.

Sumner, M.E., and W.P. Miller. 1996. Cation exchange capacity and exchange coefficients. p. 1220-1221. In D.L. Sparks (ed.). Chemical methods Methods of soil analysis part 3, book series 5. Soil Sci. Soc. Am., Madison, WI.

Thompson, M.L. and L. Ukrainczyk. 2002. Micas. p. 431-466. In J.B. Dixon and D.G. Schulze (eds.). Soil mineralogy with environmental applications, book series 7. Soil Sci. Soc. Am. Madison, WI.

Trefry, J., and S. Metz. 1985. A decline in lead transport by the Mississippi River. Science. 230 (4724): 439-441.

University of Glasgow. 2009. FEI Quanta 200F environmental scanning electron microscope [online]. Available at http://www.ges.gla.ac.uk:443/research/facilities/EnvironmentalSEM (verified 30 of February, 2009). 
U.S. Geological Survey. 2008. USGS CMG InfoBank: Suspended and dissolved loads [online]. Available at http://walrus.wr.usgs.gov/infobank/programs/html/school/moviepage/18.01.13. html (verified 5 of March, 2009).

van Olphen, H. 1977. An introduction to clay colloid chemistry ( $2^{\text {nd }}$ Edition). Interscience Publ., New York, NY.

Volk, G.M. 1937. Method of determination of the degree of dispersion of the clay fraction of soils. Soil Sci. Soc. Am. Proceedings 11: 561-565.

Wakindiki, I.I.C., and M. Ben-Hur. 2002. Soil mineralogy and texture effects on crust micromorphology, infiltration, and erosion. Soil Sci. Soc. Am. J. 66: 897905.

Wang, P., L.C. Linker, R. Batiuk, and C. Cerco. 2006. Surface analysis of Chesepeake Bay water quality response to different nutrient and sediment loads. J. Envr. Eng. 132(3): 377-383.

White, N.G. and J.B. Dixon. 2002. Kaolin-Serpentine minerals. p. 389-414. In J.B. Dixon and D.G. Schulze (eds.). Soil mineralogy with environmental applications. Soil Sci. Soc. Am., Book 7, Madison, WI.

Whittig, L.D., and W.R. Allardice. 1986. X-Ray diffraction techniques. p. 331401 In A. Klute (ed). Physical and mineralogical methods (2 ${ }^{\text {nd }}$ Edition) Methods of soil analysis, part 1. Am. Soc. Agronomy - Soil Sci. Soc. Am. Book 1, Madison, WI.

Yoon, V.K. and E.D. Stein. 2008. Natural catchments as sources of background levels of storm-water metals, nutrients, and solids. J. Envr. Eng. 134(12): 961-973. 